\title{
Geochemical and mineralogical fingerprints to distinguish the exploited ferruginous mineralisations of Grotta della Monaca (Calabria, Italy)
}

\author{
Luca Antonio Dimuccio ${ }^{\mathrm{a}, \mathrm{b}, *}$, Nelson Rodrigues ${ }^{\mathrm{c}}$, Felice Larocca ${ }^{\mathrm{b}, \mathrm{d}}$, João Pratas ${ }^{\mathrm{c}, \mathrm{e}}$, \\ Ana Margarida Amado ${ }^{\mathrm{f}}$, Luís A. E. Batista de Carvalho ${ }^{\mathrm{f}}$ \\ a Centre of Studies on Geography and Spatial Planning (CEGOT), Colégio de S. Jerónimo, University of Coimbra, 3004-530 Coimbra, Portugal \\ b Centro Regionale di Speleologia "Enzo dei Medici”, Via Lucania 3, 87070 Roseto Capo Spulico, CS, Italy \\ ${ }^{c}$ Department of Earth Sciences, Faculty of Sciences and Technology, University of Coimbra - Polo II, 3030-790 Coimbra, Portugal \\ d Gruppo di Ricerca Speleo-Archeologica, University of Bari, Piazza Umberto, 70121 Bari, Italy \\ e Marine and Environmental Sciences Centre (MARE), Faculty of Sciences and Technology, University of Coimbra, 3004-517 Coimbra, Portugal \\ ${ }^{\mathrm{f}}$ Unidade de IED “Química-Física Molecular”, Department of Chemistry, University of Coimbra, 3004-535 Coimbra, Portugal
}

\section{A R T I C L E I N F O}

\section{Article history:}

Received 5 July 2016

Received in revised form 22 September 2016

Accepted 16 October 2016

Available online 17 October 2016

\section{Keywords:}

Grotta della Monaca

Iron oxides/hydroxides

Prehistoric exploitation

Multivariate statistics

Geochemical fingerprints

Mineralogical characterisation

\begin{abstract}
A B S T R A C T
This study examines the geochemical and mineralogical variations in the ferruginous mineralisations that crop out within Grotta della Monaca, which is considered to be the most striking and best known example of a prehistoric iron mine-cave from the southern Apennines (Calabria, Italy). Previous archaeological research identified three local and distinct ancient exploitation phases of these ferruginous mineralisations: (1) an Upper Palaeolithic phase; (2) a Late Neolithic phase; and (3) a post-Medieval phase. These materials, which have various forms of complex mineralogical admixtures and range in colour from yellow-orange to red and darker brown shades, mainly consist of iron oxides/hydroxides (essentially goethite and lepidocrocite), which are often mixed with subordinate and variable amounts of other matrix components (carbonates, sulphates, arsenates, silicates and organic matter). Such ferruginous mineralisations generally correspond to geochemically heterogeneous massive dyke/vein/mammillary/stratiform facies that are exposed within the local caves along open fractures and inclined bedding planes and that partially cover cave wall niches/notches/pockets and ceiling cupolas/ holes. Selected samples/sub-samples are analysed through a multi-technique approach with a handheld portable X-ray Fluorescence, X-ray Diffraction, micro-Raman and Fourier Transform Infrared spectroscope (both conventional and attenuated total reflection), which is combined with subsequent multivariate statistical analysis of the elemental concentration data. The geochemical and mineralogical results are used to individualise similar compositional clusters. As expected, the identified groups, each of which has very specific geochemical-mineralogical "fingerprints" and spatial distributions, enable us to identify the sampled ferruginous mineralisations. These specific mineral resources can be compared to similar raw materials that are found in other neighbouring archaeological sites, with obvious implications toward understanding local exploitation strategies through time and the exchanges and kinship networks of these materials.
\end{abstract}

(c) 2016 Elsevier B.V. All rights reserved.

\section{Introduction}

The presence and use of iron minerals in certain archaeological and historical contexts, including karstic caves and rock-shelters, with a wide range of exploitation chronologies is well known in the literature (e.g., [2,5,6,19,23,24,37,39,41-45,47,68,71,73-76,85,139,167-169]). These materials, which are exposed with various forms of complex mineralogical admixtures and range in colour from red to brown and from purple to orange-yellow, consist of iron oxides/hydroxides (mainly hematite and goethite-limonite) and are often mixed with variable

\footnotetext{
* Corresponding author at: Centre of Studies on Geography and Spatial Planning (CEGOT), Colégio de S. Jerónimo, University of Coimbra, 3004-530 Coimbra, Portugal.

E-mail address: luca@ci.uc.pt (L.A. Dimuccio).
}

amounts of carbonates, silicates and other minerals. These mineral resources have provided useful and culturally significant materials because of their natural intrinsic characteristics and good compatibility with other organic and inorganic compounds (e.g., [26,36,70,78,83, 119,135-137,166,170,171]). In some archaeological sites, agglutinative substances, including egg whites and amber, were found blended with iron-rich mineral pigments (e.g., [131,145,174]).

According to some authors, these iron oxides/hydroxides and associated minerals, which are also referred to by the ambiguous and vague term "ochre" (see the reviews of $[43,54,112]$ ), were commonly used since prehistory for ceremonial, mortuary, medicinal and decorative purposes, e.g., as pigments for rock-art or body paint, pottery decoration and in association with burials $[8,14,15,22,30,31,37,41,57,70,77,133$, $137,150,153,158-160,167,173]$. Other authors argued that a symbolic 
interpretation of ochres cannot be assumed because such practices are very difficult to demonstrate, aiming more toward functional uses in ethnographic contexts, such as skin protection, tanning hides, hafting, drying and abrasive agents, filler for adhesives, etc. [43,109,134,138, 161-163,175]. However, both symbolic significance and functional value are not necessarily mutually exclusive [135]. Furthermore, the thermal treatment (heating) of yellow ochre into red ochre is well documented as a common practice during prehistory $[25,40,67,70,125,126$, $140,141]$. Thus, the attested systematic exploitation of ochre, which is still surrounded by a controversial interpretative framework, is often understood as evidence of colour symbolism and a proxy for the origin of language [26,38,72,82-84,166,172].

Because of its ambiguity and considering the focus of this paper (i.e., mineral resources), the term "ochre" is avoided henceforth in the text and the more consensual and generic expression of "ferruginous mineralisation" is used instead, which means iron oxides/hydroxides with associated matrix minerals.

The elemental, mineralogical or isotopic characterisation of ferruginous mineralisations from geological outcrops and archaeological assemblages has become increasingly common for geoarchaeological interpretations, particularly to support the identification of ancient mining strategies and the construction of resource use-trade-exchange models (e.g., $[2,20,24,25,33,55,58,63,81,112,113,116,123,127-130,142$, $148,154]$ ). Even if the cultural implications of the use of ferruginous mineralisations are fairly well documented through the study of raw materials and archaeological artefacts, very little is usually known regarding their systematic procurement, exploitation and processing strategies during prehistory. Thus, we must establish a precise geochemical and mineralogical characterisation of these exploited materials and their local exposure conditions to interpret ancient mining practices in detail $[112,128]$.

As a working hypothesis, the choices (in space and time) of prehistoric peoples regarding available iron-rich mineral resources in a specific geomorphological context (e.g., a cave) may have depended on or were strongly influenced by these materials' intrinsic characteristics/ qualities, including colour richness, texture/fabric, friability, covering strength, malleability, etc., in accordance with their intended functions. These choices, in turn, mainly depended on their ultimate geochemical and mineralogical compositions. Bearing in mind these general considerations, this study aims to investigate the ferruginous mineralisations that crop out within the archaeological iron mine-cave of Grotta della Monaca (southern Italy). This research is conducted from a geochemical and mineralogical perspective to identify the possible geochemicalmineralogical trends of these available materials as a first step to identify local prehistoric exploration strategies. This study's results could be used to demonstrate if Grotta della Monaca was the geological source for iron-rich red-yellow raw materials that are found in other archaeological sites.

\section{Cave Description}

Grotta della Monaca, which is located in the municipality district of Sant'Agata di Esaro (Calabria, Italy), only $12 \mathrm{~km}$ from the Tyrrhenian Sea, is a complex (hypo-/epigenic) karstic cave that represents the most striking and best known example of a prehistoric iron mine in the southern Apennines. Its entrance is located on the northern side of the deeply incised fluviokarst Esaro Valley at an altitude of $600 \mathrm{~m}$ (Fig. 1).

This cave was developed in a carbonate lithology (mainly dolostones, dolomitic-limestones and limestones; see [48]) that belongs to the so-called San Donato unit, which corresponds to a 3000-m-thick sedimentary succession of Triassic $[3,13,89]$. Primary scattered mineralisations occur in the San Donato unit, which basically consist of barite $\left[\mathrm{BaSO}_{4}\right]$ and mixed sulphides such as chalcopyrite [ $\left.\mathrm{CuFeS}_{2}\right]$, arsenopyrite [FeAsS], pyrite $\left[\mathrm{FeS}_{2}\right]$, galena $[\mathrm{PbS}]$ and cinnabar $[\mathrm{HgS}]$. The barite mineralisations are mostly concentrated along the intersections of tectonic faults [11], while the sulphides are mostly concentrated in lenses and veins within fractures and in bedding planes [110].

From a morphological perspective, the cave is characterised by few spaces that can be schematically divided into three main sectors (Fig. 2 ): the Pregrotta, a wide gallery near the entrance that is oriented to the NE; the Sala dei pipistrelli, a huge chamber that is $60 \mathrm{~m}$ long and $30 \mathrm{~m}$ wide; and the Cunicoli terminali, a series of low and narrow passages at the eastern cave termination $[49,92,100]$.

In addition to the common minerals of an underground carbonate karst environment (e.g., calcite), significant outcrops of heterogeneous massive ferruginous mineralisations were previously observed in the cave $[50,52,99]$. These ferruginous mineralisations, which range in colour from yellow-orange to red and darker brown shades, often occur as specific facies types (Fig. 3): (a) massive dyke/vein facies, which fill

\section{GEOGRAPHICAL SETTING OF THE UPPER ESARO VALLEY}
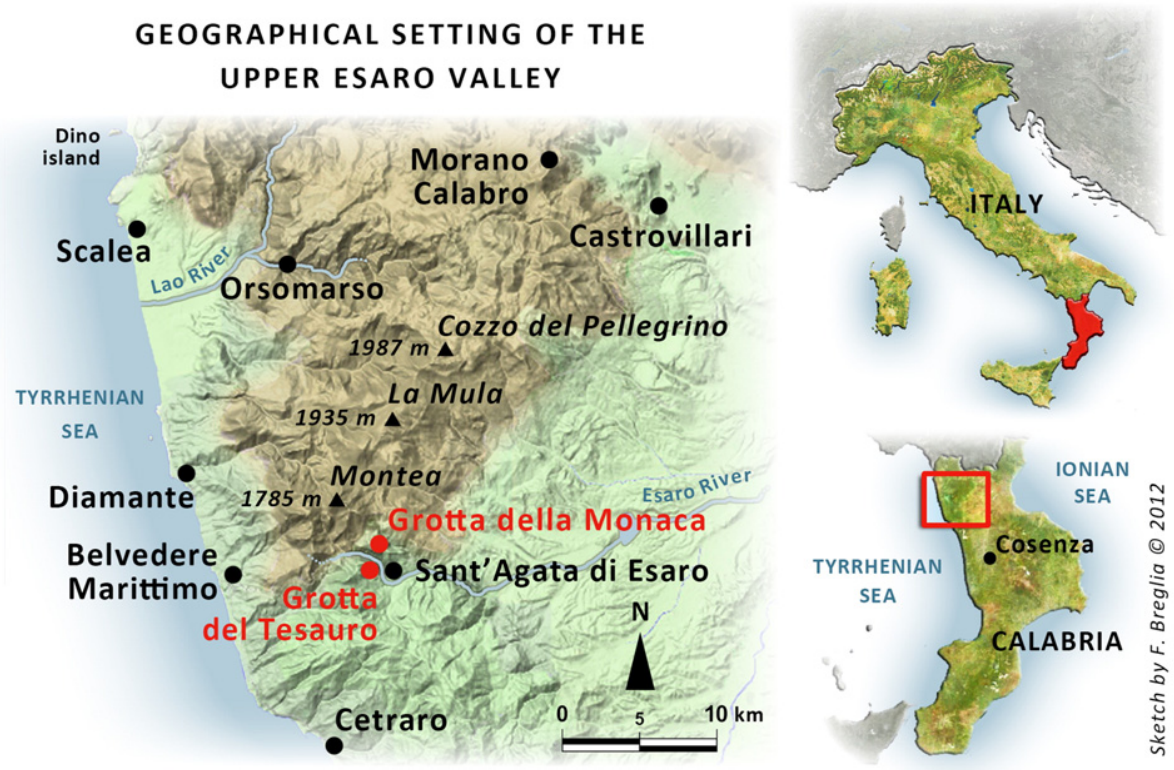

Fig. 1. Geographical setting of the Upper Esaro valley. The red points indicate the location of the main prehistoric iron mine-caves. 


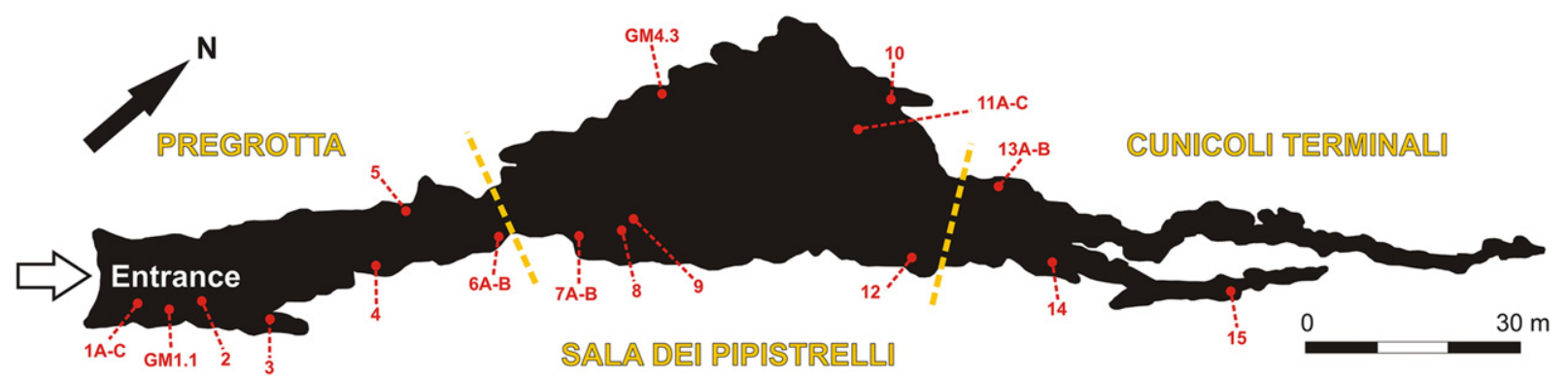

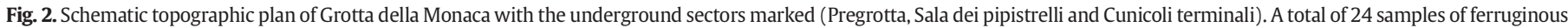
mineralisations were collected in the main sectors of the cave, at variable depths wherever possible, from 17 selected sampling sites (i.e., the red points).

open fractures and highly inclined solution-widened bedding planes, with a symmetric fabric from the walls that often leaves a void or shows (b) box-work structures in the central fracture area; (c) massive mammillary and (d) stratiform facies, which partially cover cave wall niches/notches/pockets and ceiling cupolas/holes; (e) earthy and incoherent varieties, which generally accumulated on the cave floor and resulted from the weathering of the above facies; and (f) very small black concretion facies, which hang from the cave ceiling. Small quantities of other carbonates (aragonite and dolomite), copper carbonates (malachite and azurite), sulphates (jarosite), phosphates (sampleite, hydroxylapatite, libethenite and an undetermined calcium-phosphate), arsenates (yukonite and scorodite) and silicates (planchéite, gilatite, apachite, and an undetermined copper-silicate) were also detected on the cave floor/walls as separated minerals with respect to these ferruginous mineralisations [50-52,65,99].

Archaeological investigations and regular excavation campaigns within Grotta della Monaca, which were authorised by the "Ministero dei Beni e le Attività Culturali", were conducted from 2000 to 2012 by the University of Bari (Italy). However, accurate documentation and studies of this underground archaeological site were initiated and led by the "Centro Regionale di Speleologia Enzo dei Medici" in 1997 (Fig. 4).

The most ancient human presence in the cave can be correlated to the Upper Palaeolithic, as evidenced by the occurrence of a restricted number of flint flakes/tools that were preserved in the exposed ferruginous mineralisations near the cave entrance and by the discovery of a human ulna under a nearby isolated and large carbonate rocky block [104,107], which was dated by ${ }^{14} \mathrm{C}$ to $16,761 \pm 100 \mathrm{yr}$ BP (sample LTL3580A; [132]) and indicates the first iron mining activity in Grotta della Monaca [94,102]. However, well-planned and intense exploitation of this cave only occurred at the end of the Neolithic, as indicated by many ${ }^{14} \mathrm{C}$ dates on charcoals (i.e., residues of wooden torches that were used by miners during the excavation activities) (see [94,132]). As supported by previous ${ }^{14} \mathrm{C}$ dating, the interpretative archaeological framework indicated that important mining fronts were opened in the underground cave sectors, which showed abundant outcrops of ferruginous mineralisations, between the late 5 th and early 4 th millennium BC $[94,98,102,103,107]$. According to these authors, these mining activities within the cave could be proven by the presence of the following archaeological evidence: (i) several hundred digging traces on the soft ferruginous mineralisations, which were left as negative imprints by tools that were mostly made of bones, deer antlers and possibly wood (Fig. 4); (ii) stonewalls, which mainly consisted of small blocks of ferruginous mineralisations and were usually erected in cramped cave areas to rationally organise space and mining wastes; and (iii) pillars, which were created by using specific blocks of ferruginous mineralisations to support the ceiling where it was in danger of collapsing.

Subsequently, Grotta della Monaca assumed the function of a vast burial ground, as confirmed by the presence of several human remains that were discovered in the deepest sector of the cave $[4,16]$, all of which were dated by ${ }^{14} \mathrm{C}$ to the 2 nd millennium $\mathrm{BC}$ during the Bronze
Age [132]. Ferruginous mineralisation mining activities resumed during the 17th-18th century in the post-Medieval period, as recognised by the fragmentary ceramics that have been found in some underground mining areas [94]. This most recent extractive phase was observed in two parallel and extended $(>100 \mathrm{~m})$ galleries, which were artificially dug in ferruginous mineralisations veins under the natural ground of the Pregrotta and Sala dei pipistrelli cave sectors. The walls of these two artificial conducts still preserve numerous traces of excavations because of metallic picks [94].

Previous scientific works on the different minerals within Grotta della Monaca [50-52,65,99] provided their minerogenetic characterisation and were an indispensable complement to geomorphological [49, 100], archaeological [66,91-98,101-103,107] and anthropological [4, 16] research. However, no systematic studies on the geochemistry and distribution of the heterogeneous massive ferruginous mineralisations in Grotta della Monaca currently exist.

\section{Materials and Methods}

\subsection{Sampling and Analytical Methods}

New sampling campaigns of these ferruginous mineralisations were conducted during the winter of 2012 and the summer of 2015. A total of 24 samples $(\sim 1 \mathrm{~kg}$ each) were collected in the main geomorphological sectors of the cave, at variable depths wherever possible, from 17 selected sampling sites (Fig. 2). In addition, 3 samples were collected from two sites located within another very similar cave nearby (i.e., Grotta del Tesauro, a smaller sub-horizontal karst conduct that is $\sim 50 \mathrm{~m}$ in length; $[103,117])$ that opens on the opposite side of the Esaro Valley at an altitude of $500 \mathrm{~m}$ (Fig. 1).

Most of the selected sampling sites were chosen because of their previously inferred archaeological meaning, especially in terms of the spatial and/or chronological representativeness of the areas that were devoted to ancient mining exploitations. Other sampling sites were selected based on the occurrence of the above-mentioned ferruginous mineralisations facies types. Collecting multiple samples from the same site enabled us to investigate the degree of homogeneity within Grotta della Monaca (intra-cave variations) through a more complete description of each site and provided a more robust statistical evaluation. Preliminary inter-cave variations/similarities between Grotta della Monaca and Grotta del Tesauro were also documented. During the field work, both caves were also investigated from a geomorphological and structural-geology perspective to reconstruct their complex polygenic/polyphase - speleogenetic evolution and thus enable us to integrate new geochemical and mineralogical data and archaeological interpretations into a wider regional geoarchaeological framework.

All the samples $(24+3)$ were subjected to a standard pre-treatment protocol after the field work and before conducting the laboratory analyses because of the already attested heterogeneous nature of the ferruginous mineralisations that are under investigation [50,52,99]: (a) first, the samples were dried at $50{ }^{\circ} \mathrm{C}$ in an oven over two days to remove 

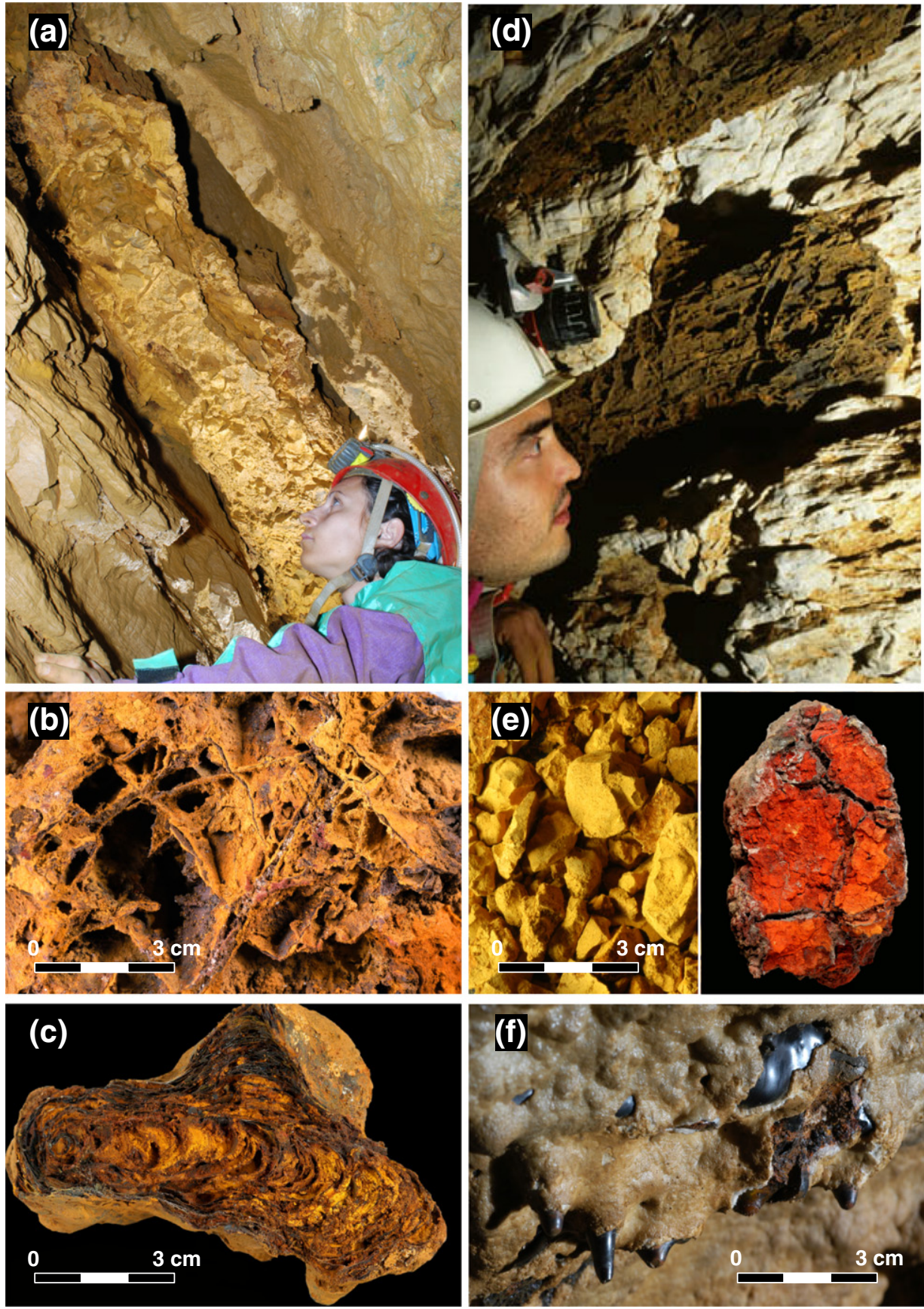

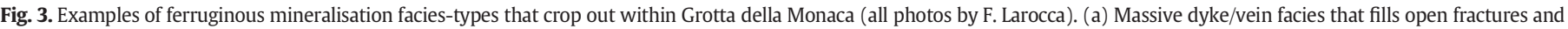

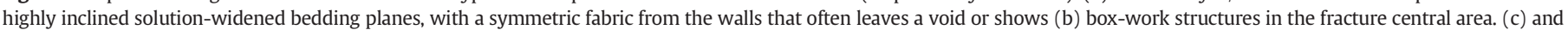

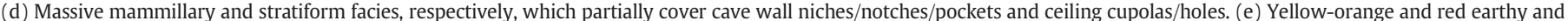
incoherent varieties of ferruginous mineralisations. (f) Very small black concretions facies that hang from the cave ceiling.

moisture; (b) subsequently, each sample was crushed with a rock hammer into smaller pieces; (c) 72 laboratory sub-samples from Grotta della Monaca and 9 sub-samples from Grotta del Tesauro were accurately separated based on clearly distinctive characteristics (colour and/or texture/fabric/relative tenacity) that were observed at a mesoscale and confirmed at a micro-scale through binocular/petrographic microscopic inspection; and (d) an aliquot of each sub-sample was homogenised/milled in an agate mortar and reduced to a fine powder (grain size $<30 \mu \mathrm{m}$ ) to perform some of the subsequent laboratory analyses.

We used the laboratory facilities at the Earth Sciences Department of Coimbra University. All the sub-samples were analysed by a battery- powered handheld portable X-ray fluorescence spectrometer (Thermo Scientific ${ }^{\mathrm{TM}}$ Niton ${ }^{\mathrm{TM}}$ XL3t 950 GOLDD + XRF Analyser with a geometrically optimized large area silicon drift detector technology that was equipped with an $\mathrm{Ag}$ anode X-ray tube of $6-50 \mathrm{kV}$ and 0-200 $\mu \mathrm{A}$ max) to achieve an initial and quick discrimination based on major and minor element concentration trends with minimal sample preparation. This instrument uses in-factory calibrations that are based on fundamental parameter (FP) analysis and Compton Normalisation $[60,69]$ to measure samples of unknown chemical composition, in which the concentrations of heavy and light elements may vary from high percent levels to parts per million. Handheld portable X-ray Fluorescence (pXRF) generally enabled us to detection most elements with an atomic 

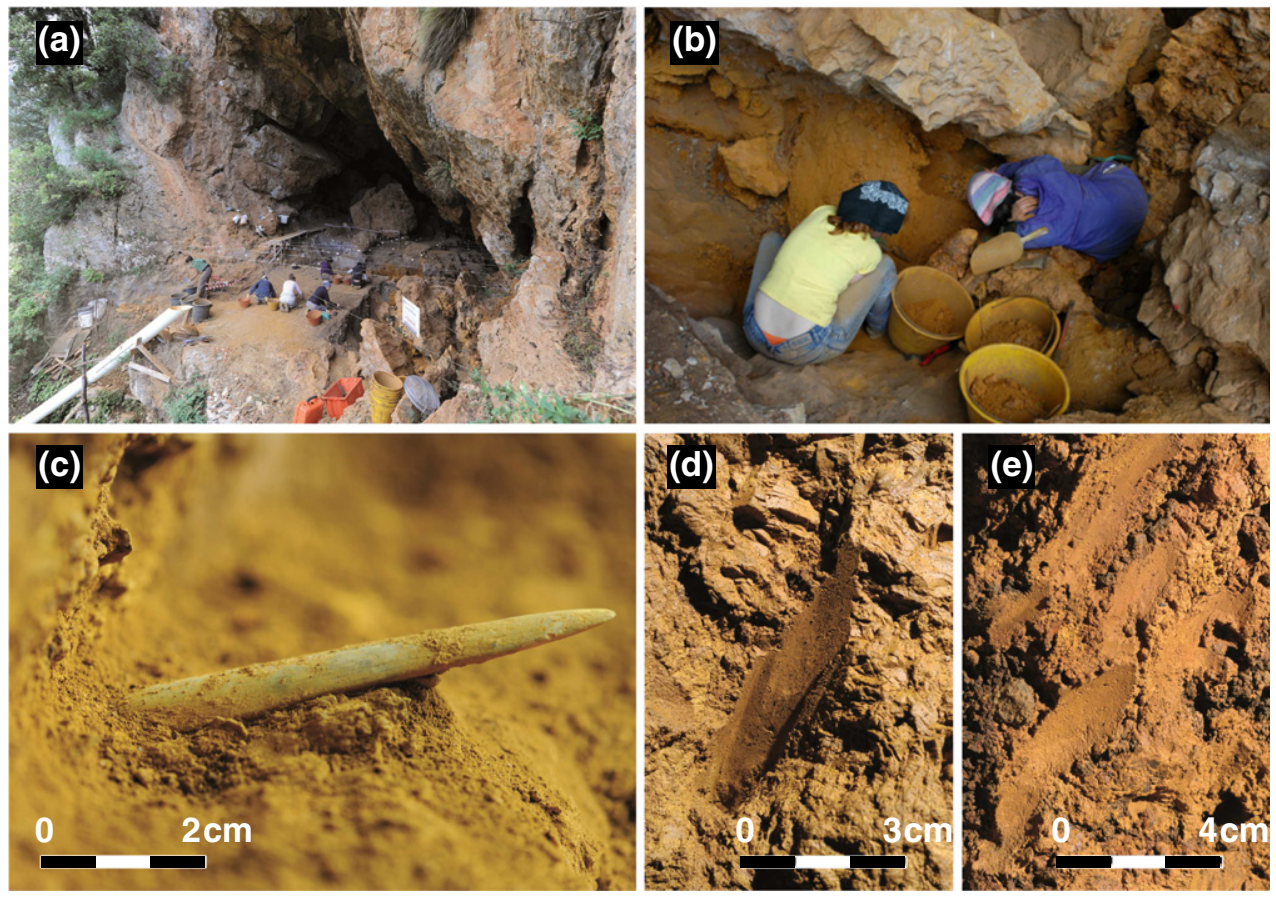

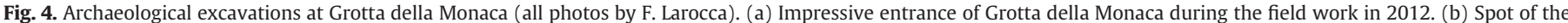

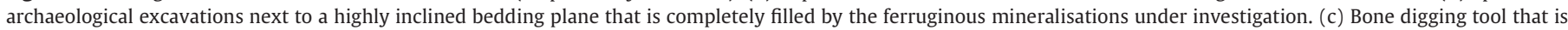

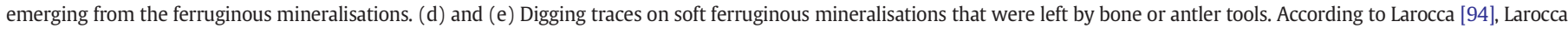
and Levato [102] and Larocca and Breglia [103], (c), (d) and (e) indicate ancient mining activities in the cave since the Upper Palaeolithic, among other archaeological evidence.

number above sodium (see the reviews of $[151,176])$. Each powdered sub-sample was weighed to $\sim \mathrm{g}$ and sealed (without a binder) into a small plastic cup with a $1 / 4$ mil $(6.35 \mu \mathrm{m})$ transparent polypropylene measuring window. Measurements were acquired in the air with a constant working distance by using a lead receptacle (bench-top accessory stand for operation in the laboratory), to which the spectrometer was fixed (with the nose upwards). A built-in camera assisted with the sub-sample positioning, minimising geometric errors. Each sub-sample was scanned for a duration of $120 \mathrm{~s}$ per beam. The spot size on this specific instrument was $8 \mathrm{~mm}$ in diameter. The TestAll ${ }^{\mathrm{TM}} \mathrm{Geo}$ mode (algorithm supplied by the instrument manufacturer) was used to measure the concentrations of $\mathrm{Ag}, \mathrm{Al}, \mathrm{As}, \mathrm{Ba}, \mathrm{Ca}, \mathrm{Cl}, \mathrm{Co}, \mathrm{Cr}, \mathrm{Cs}, \mathrm{Cu}, \mathrm{Fe}, \mathrm{K}, \mathrm{Mg}, \mathrm{Mn}$, $\mathrm{Mo}, \mathrm{Nb}, \mathrm{Ni}, \mathrm{Pb}, \mathrm{Rb}, \mathrm{Sb}, \mathrm{Sc}, \mathrm{Si}, \mathrm{Sn}, \mathrm{S}, \mathrm{Sr}, \mathrm{Te}, \mathrm{Ti}, \mathrm{V}, \mathrm{W}, \mathrm{Zn}$ and Zr. Data quality assurance and control were performed by tripling each measurement.

The accuracy of the pXRF instrument was tested (for the elements of interest in this study) by using the NIST SRM 2709a San Joaquin Soil certified standard material [114], prior to the pXRF measurements of the sampled ferruginous mineralisations [59]. The pXRF measurements of the powder standard material were checked against the established/accepted and certified concentration values (see supplementary materials - Table S1). The percent relative difference and the coefficient of variation $(\mathrm{CV})$ between the measured pXRF-reported and the published NIST-certified concentrations were calculated. Some elements exhibited better agreement than others. However, some broad correspondence existed, with a relative difference of $<18 \%$ in all cases except for $\mathrm{Al}, \mathrm{Cr}$, $\mathrm{Mg}, \mathrm{Pb}, \mathrm{Rb}$ and $\mathrm{Zr}$. Fe, As, Ca, Cu, Ni, Sr, Ti, V and $\mathrm{Zn}$ showed the closest agreement with the NIST-certified values (relative differences below $10 \%)$. A perfectly accurate pXRF instrument would yield data with a $\mathrm{CV}$ of zero (distributions with $\mathrm{CV}<1$ are considered low variance, while those with $\mathrm{CV}>1$ are considered high variance). The calculated CV indicates low variance between the two compared datasets (Table $\mathrm{S} 1$ ), which demonstrates that this pXRF instrument was sufficiently accurate and reliable to characterise mineral resources.

Mineralogical analyses were conducted with X-ray Diffraction (XRD) by using a Philips PW 3710 diffractometer, which was equipped with a $\mathrm{CuK} \alpha \mathrm{X}$-ray tube $\left(\mathrm{CuK} \alpha_{1}=1.54056 \AA\right)$ and a detector that operated at $40 \mathrm{kV}$ and $20 \mathrm{~mA}$, and by applying the powder method. Continuous scans with a time per step of $0.1 \mathrm{~s}$ between $2^{\circ}$ and $60^{\circ}$ (of $2 \theta$ ) with a step size of $0.02^{\circ}$ were executed on non-oriented powder samples. The PW1877-APD 3.3.j software (by Philips) and the correlated PDF-2 database (PCPDFWIN), which was licensed by the ICDD (International Centre for Diffraction Data), and RRUFF mineralogical database (www.rruff. info - last access March 2016) were simultaneously used to identify the mineral phases. This mineral identification and a more detailed characterisation of the molecular structure were complemented by microRaman and Fourier Transform Infrared spectroscopy (both conventional and attenuated total reflection).

The Raman spectra were recorded at "Química-Física Molecular" (University of Coimbra) on a Horiba Jobin-Yvon T64000 spectrometer in direct configuration mode (focal distance of $0.640 \mathrm{~m}$, aperture of $\mathrm{f}$ / 7.5 ) that was equipped with a holographic grating of 1800 grooves $\mathrm{mm}^{-1}$. The entrance slit was set to $200 \mu \mathrm{m}$. Rayleigh elastic scattering was rejected by a Notch filter, which reduced its intensity by a factor of $10^{6}$. The detection system was a liquid-nitrogen-cooled non-intensified $1024 \times 256$-pixel ( $\left.1^{\prime \prime}\right)$ CCD. The 514.5-nm line of an $\mathrm{Ar}^{+}$laser (Coherent, model Innova 90C-04) was used as the excitation radiation, which yielded 10 to $2 \mathrm{~mW}$ at the sample position. All the spectra were recorded by using an Olympus $50 \times$ objective. A $200-\mu \mathrm{m}$ confocal pinhole rejected signals from out-of-focus regions of the sample. Two aliquots from each sample were recorded, for which 4 to 7 distinct continuous scans were performed (acquisition times of $60 \mathrm{~s}$ ). The final spectra for each sample were the average of three independent measurements.

Conventional Fourier Transform Infrared (FTIR) spectra were recorded at "Química-Física Molecular" (University of Coimbra) by a Bruker Optics Vertex 70 FTIR spectrometer, which was purged by $\mathrm{CO}_{2}$-free dry air in the $400-4000 \mathrm{~cm}^{-1}$ range by using $\mathrm{KBr}$ disks (ca. $1 \% \mathrm{w} / \mathrm{w}$ ), a $\mathrm{KBr}$ beam splitter, and a liquid-nitrogen-cooled Mercury Cadmium Telluride (MCT) detector. Moreover, the Attenuated Total Reflection Infrared (ATR-FTIR) spectra were recorded 
at the Laboratório Associado CICECO of the University of Aveiro on an IFS 55 spectrometer by using a Golden Gate single-reflection diamond ATR system, with no need for sample preparation. All the FTIR-KBr and ATR-FTIR spectra were the average of two counts of 128 scans each. A spectral resolution of $2 \mathrm{~cm}^{-1}$ was used in all cases.

\subsection{Statistical Treatment of Data}

The elemental concentrations of each sub-sample were normalised to the Fe content (henceforth referred to as Fe-normalised elements) and then converted to a base-10 logarithmic format $\left(\log _{10}\right)$ to perform a correct multivariate treatment of the selected geochemical dataset. This procedure corresponds to the standard protocol that is used when attempting to execute a multivariate statistical analysis of the elemental concentrations of mineralisations, which show various data that reach several orders of magnitude within the set [9]. Indeed, the attested high variability of the Fe concentrations across the analysed dataset can dilute or amplify the presence of other potentially diagnostic chemical elements, or where other elements may substitute for Fe [112].

The multivariate statistical treatment of $\log _{10}$ Fe-normalised element concentrations was used to understand how variable the subsamples were and which chemical elements controlled the variance within the dataset and to eventually differentiate geochemical patterns or groups independently from the spatial extension and location of the collected samples [164]. Specifically, principal component analysis (PCA) and hierarchical clustering analysis (HCA) were employed to quantitatively search for relationships among the geochemical values of the analysed sub-samples. PCA is commonly used in earth sciences to simplify data structures by reducing the dimensions of the data. The original parameters are rearranged into several new uncorrelated comprehensive principal components (PCs) without losing significant information [18]. Each new component is a linear combination of the original variables and unrelated, which makes this process accurate enough to describe the characteristics of the analysed data. Only PCs with eigenvalues $>1$ were retained for interpretation. Moreover, PCA interpretation was based on examinations of the correlations between the variables and the obtained PCs. Then, HCA was performed based on the previously executed PCA to quantify the similarity of the sub-samples. In HCA, the factor scores that were obtained in PCA were used as variables for statistical grouping [28]. Bivariate scatterplots of element concentration pairs were also useful to show their possible correlations and groups. PCA, HCA and scatterplots were conducted by using the R Language (R Core Team, [178]) and its package FactoMineR [79]. Confidence ellipses were drawn on the scatterplots with a concentration level of 0.5 to better visualise the geochemical patterns and to describe the probability of group affiliation.
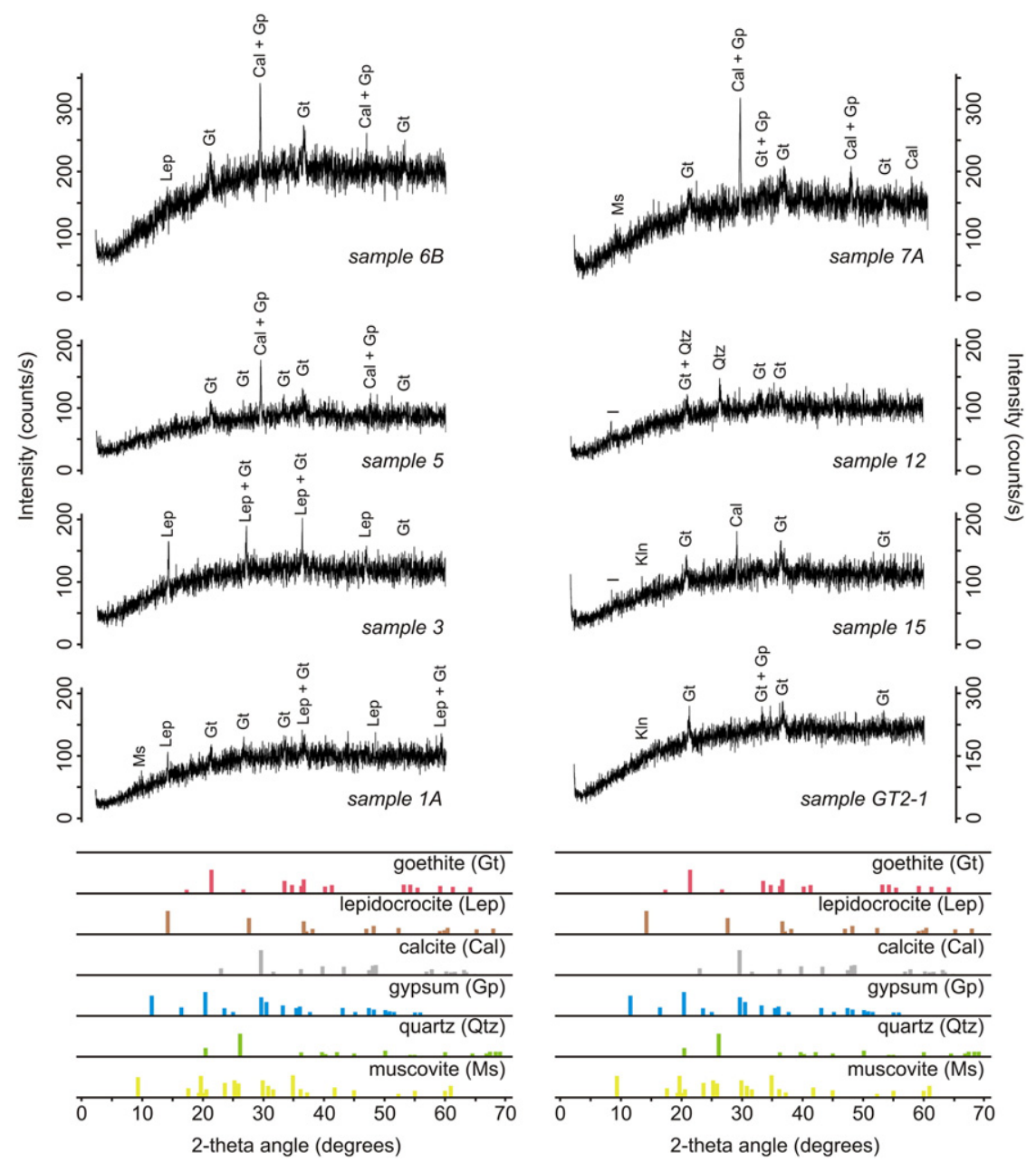

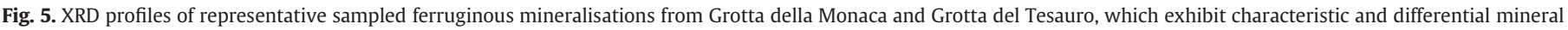

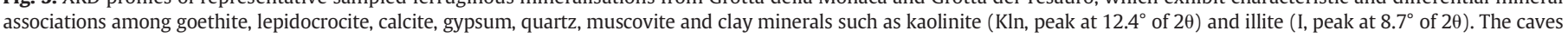
and selected sampling sites are spatially indicated in Figs. 1 and 2. 


\section{Results}

\subsection{Elemental Concentration and Mineralogical Data}

The geochemical results are summarised in a large table and reported as electronic supplementary material in the online version of the journal (Table S2). Despite the constant presence of bat guano within the Grotta della Monaca, especially in the Sala dei pipistrelli, and the presence of important varieties of secondary calcium and copper-phosphates minerals, no amounts of P were detected by pXRF, possibly because of instrumental limits. The raw geochemical data illustrated prominent differences among the main geomorphological cave sectors (or even among sampling sites, often with archaeological meaning) of Grotta della Monaca, with some similarities in their transition zones and between samples from the entrance of this cave and Grotta del Tesauro. Because the analysed sub-samples obviously mainly consist of iron minerals, the Fe concentration across the dataset was highly variable, ranging from $61.8 \%$ to $25.1 \%$. When the sub-samples displayed the lowest Fe concentration values, the main components of carbonate and silicates in the matrix (e.g., $\mathrm{Ca}, \mathrm{Mg}$ and $\mathrm{Si}$ ) often constituted the difference in the total amount of the sub-sample's elemental concentration. A more detailed differentiation in geochemical trends or groups requires advanced/stepwise statistical analysis of the available geochemical dataset.

The mineralogical results confirm that all the non-oriented powder XRD analysed sub-samples consist of a clear admixture of iron oxides/ hydroxides, where the most abundant phases are goethite $[\alpha-$
$\mathrm{FeO}(\mathrm{OH})](\mathrm{Gt})$ and its polymorph lepidocrocite $[\gamma-\mathrm{FeO}(\mathrm{OH})]$ (Lep), which is associated with small and subordinate quantities of other matrix minerals, including calcite $\left[\mathrm{CaCO}_{3}\right](\mathrm{Cal})$, quartz $\left[\mathrm{SiO}_{2}\right](\mathrm{Qtz})$, muscovite $\left[\mathrm{KAl}_{2}\left(\mathrm{AlSi}_{3} \mathrm{O}_{10}\right)(\mathrm{OH})_{2}\right](\mathrm{Ms})$, gypsum $\left[\mathrm{CaSO}_{4} \cdot 2 \mathrm{H}_{2} \mathrm{O}\right](\mathrm{Gp})$ and clay minerals such as kaolinite $\left[\mathrm{Al}_{2} \mathrm{Si}_{2} \mathrm{O}_{5}(\mathrm{OH})_{4}\right](\mathrm{Kln})$ and illite $\left[\left(\mathrm{K}, \mathrm{H}_{3} \mathrm{O}\right)(\mathrm{Al}, \mathrm{Mg}, \mathrm{Fe})_{2}(\mathrm{Si}, \mathrm{Al})_{4} \mathrm{O}_{10}\left[(\mathrm{OH})_{2},\left(\mathrm{H}_{2} \mathrm{O}\right)\right]\right.$ (I) (Fig. 5). Limonite $\left[\mathrm{FeO}(\mathrm{OH}) \cdot \mathrm{nH}_{2} \mathrm{O}\right](\mathrm{Lm})$, maghemite $\left[\gamma-\mathrm{Fe}_{2} \mathrm{O}_{3}\right](\mathrm{Mgh})$ and hematite $[\alpha-$ $\mathrm{Fe}_{2} \mathrm{O}_{3}$ ] (Hem) were only detected in few sub-samples (Table 1 ).

Further evidence of the mineralogical assemblage that characterises these ferruginous mineralisations was also provided by micro-Raman and FTIR spectroscopy (Table 1 and Figs. 6 and 7). In addition to all the phases that were detected by XRD in the sampled ferruginous mineralisations, anatase $\left[\mathrm{TiO}_{2}\right]$ (Ant), brochantite $\left[\mathrm{Cu}_{4}\left(\mathrm{SO}_{4}\right)(\mathrm{OH})_{6}\right]$ (Bro), arsenosiderite $\left[\mathrm{Ca}_{2} \mathrm{Fe}_{3} \mathrm{O}_{2}\left(\mathrm{AsO}_{4}\right)_{3} \cdot 3 \mathrm{H}_{2} \mathrm{O}\right]$ (Asd), lavendulan $\left[\mathrm{NaCaCu}_{5}\left(\mathrm{AsO}_{4}\right)_{4} \mathrm{Cl} \cdot 5 \mathrm{H}_{2} \mathrm{O}\right]$ (Lvd) and some organic material (black and amorphous carbon) were identified by micro-Raman and/or FTIR as matrix minerals that were intimately associated with goethite and/ or lepidocrocite. Particularly interesting are the strong and broad Raman bands at 1341 and $1601 \mathrm{~cm}^{-1}$, which match the $\mathrm{sp}^{2}$ carbon disorder (D) and graphitic (G) bands, respectively. In fact, the intensity ratio of these signals and the G-band's full width at half maximum (FWHM), have been routinely used to characterise carbon-based materials $[17,32,90]$. For amorphous carbon, conventional FTIR showed a very strong band at ca. $1385 \mathrm{~cm}^{-1}$, which was possibly associated with cation exchange between nitrates $\left(\mathrm{NO}_{3}^{-}\right)$and most likely related to bat guano and the potassium bromide $[\mathrm{KBr}]$ that was used to prepare the pellets, facilitated by mechanical pressure during the pelleting

Table 1

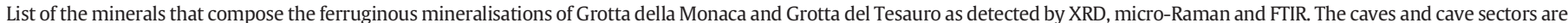

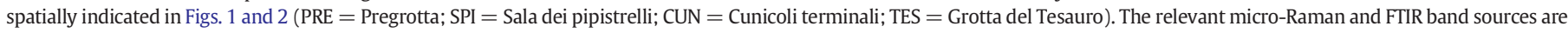
reported within the square brackets in their respective columns.

\begin{tabular}{|c|c|c|c|c|c|}
\hline Group & Mineral & Composition & Observed micro-Raman bands $\left(\mathrm{cm}^{-1}\right)^{\mathrm{a}}$ & $\begin{array}{l}\text { Observed FTIR bands } \\
\left(\mathrm{cm}^{-1}\right)^{\mathrm{a}}\end{array}$ & $\begin{array}{l}\text { Cave and } \\
\text { cave-sector }\end{array}$ \\
\hline \multirow[t]{6}{*}{ Oxides/hydroxides } & Goethite & $\alpha-\mathrm{FeO}(\mathrm{OH})$ & $294(\mathrm{~s}), 396$ (vs), 468, 542, 680 - [1] [2] [3] & $795(s), 892(s)-[4]$ & $\begin{array}{l}\text { PRE; SPI; } \\
\text { CUN; TES }\end{array}$ \\
\hline & Lepidocrocite & $\gamma-\mathrm{FeO}(\mathrm{OH})$ & $247,281,343,374,520-[2][5]$ & $739,1015(s), 1159-[27]$ & PRE \\
\hline & Limonite & $\mathrm{FeO}(\mathrm{OH}) \cdot \mathrm{nH}_{2} \mathrm{O}$ & $364(s), 393$ (vs), 896 (s) - [7] & & CUN \\
\hline & Maghemite & $\gamma-\mathrm{Fe}_{2} \mathrm{O}_{3}$ & $350,500,700-[5]$ & & PRE; TES \\
\hline & Hematite & $\alpha-\mathrm{Fe}_{2} \mathrm{O}_{3}$ & 216, 290, $398(\mathrm{~s}), 1300(\mathrm{~s} / \mathrm{b})-[1][7]$ & $\begin{array}{l}405(\mathrm{~s}), 463(\mathrm{w}), 610(\mathrm{~m})- \\
{[6]}\end{array}$ & $\begin{array}{l}\text { PRE; SPI; } \\
\text { CUN; TES }\end{array}$ \\
\hline & Anatase $e^{b, d}$ & $\mathrm{TiO}_{2}$ & $144(\mathrm{vs}), 394,623-[8][9]$ & & SPI; CUN \\
\hline Carbonates & Calcite $^{\mathrm{b}}$ & $\mathrm{CaCO}_{3}$ & $\begin{array}{l}153(\mathrm{~m}), 277(\mathrm{~s}), 711(\mathrm{~m}), 1086(\mathrm{vs}), 1434 \\
(\mathrm{w}), 1747(\mathrm{w})-[10][11][12]\end{array}$ & $\begin{array}{l}712(\mathrm{~s}), 877(\mathrm{vs}), 1425(\mathrm{~s})- \\
{[10]}\end{array}$ & $\begin{array}{l}\text { PRE; SPI; } \\
\text { CUN; TES }\end{array}$ \\
\hline \multirow[t]{2}{*}{ Sulphates } & Gypsum $^{\text {b }}$ & $\mathrm{CaSO}_{4} \cdot 2 \mathrm{H}_{2} \mathrm{O}$ & $366,409,666,1004$ (vs), 1131 - [10] [17] & $\begin{array}{l}603(s), 669(s), 1621(s) \\
1685(s)-[10]\end{array}$ & $\begin{array}{l}\text { PRE; SPI; } \\
\text { TES }\end{array}$ \\
\hline & Brochantite $^{\mathrm{b}, \mathrm{d}}$ & $\mathrm{Cu}_{4}\left(\mathrm{SO}_{4}\right)(\mathrm{OH})_{6}$ & $394,1066,1082,1160-[13][14]$ & $\begin{array}{l}424(s), 485(s), 599(s), 875 \\
(s), 1028(s), 1114(s)-[13]\end{array}$ & SPI \\
\hline \multirow[t]{2}{*}{ Arsenates } & $\begin{array}{l}\text { Arsenosiderite } \\
\text { d }\end{array}$ & $\mathrm{Ca}_{2} \mathrm{Fe}_{3} \mathrm{O}_{2}\left(\mathrm{AsO}_{4}\right)_{3} \cdot 3 \mathrm{H}_{2} \mathrm{O}$ & $152,216,390(s)-[15]$ & & $\begin{array}{l}\text { PRE; SPI; } \\
\text { CUN; TES }\end{array}$ \\
\hline & Lavendulan ${ }^{\mathrm{b}, \mathrm{d}}$ & $\mathrm{NaCaCu}_{5}\left(\mathrm{AsO}_{4}\right)_{4} \mathrm{Cl} \cdot 5 \mathrm{H}_{2} \mathrm{O}$ & $176,229,268-[16]$ & $764,861,922,1644$ - [16] & $\begin{array}{l}\text { PRE; SPI; } \\
\text { TES }\end{array}$ \\
\hline \multirow[t]{4}{*}{ Silicates } & Quartz $^{\mathrm{b}}$ & $\mathrm{SiO}_{2}$ & $\begin{array}{l}390(w), 463(v s), 693(w), 803(w)-[3] \\
{[17]}\end{array}$ & $457,1082(s)-[18]$ & SPI \\
\hline & Muscovite $^{\mathrm{b}}$ & $\mathrm{KAl}_{2}\left(\mathrm{AlSi}_{3} \mathrm{O}_{10}\right)(\mathrm{OH})_{2}$ & 262 (vs), 419 (b), 703 (s) - [19] & $\begin{array}{l}416(s), 472(s), 521(s) \\
1025(s), 1078(s)-[19]\end{array}$ & PRE; SPI \\
\hline & Kaolinite $^{\mathrm{b}}$ & $\mathrm{Al}_{2} \mathrm{Si}_{2} \mathrm{O}_{5}(\mathrm{OH})_{4}$ & 127 (s/sp), $262(w), 400-[8][20]$ & $914,1009,1032,1098-[30]$ & CUN; TES \\
\hline & Illite $^{\mathrm{b}}$ & $\left(\mathrm{K}, \mathrm{H}_{3} \mathrm{O}\right)(\mathrm{Al}, \mathrm{Mg}, \mathrm{Fe})_{2}(\mathrm{Si}, \mathrm{Al})_{4} \mathrm{O}_{10}\left[(\mathrm{OH})_{2},\left(\mathrm{H}_{2} \mathrm{O}\right)\right]$ & $413,623,633,710,790-[28][29]$ & $\begin{array}{l}468,525,622,688,756,832 \\
916,1031 \text { (vs), } 1090-[30]\end{array}$ & SPI; CUN \\
\hline \multirow[t]{2}{*}{ Organic matter } & Black carbon $^{\text {b, d }}$ & Disorder and graphitic carbon & 1341 (s/b), $1601(\mathrm{~s})-[21][22][23][26]$ & & PRE \\
\hline & $\begin{array}{l}\text { Amorphous } \\
\text { carbon }^{\text {b, d }}\end{array}$ & Bat guano & & $1385(v s)^{c}-[24][25][26]$ & PRE; SPI \\
\hline
\end{tabular}

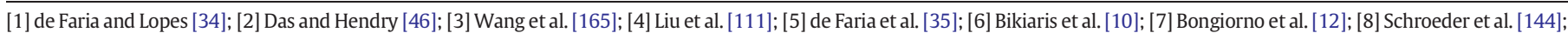

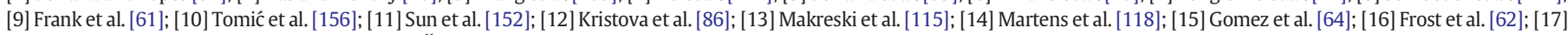

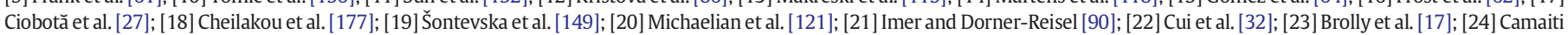
et al. [21]; [25] Kurtikyan et al. [88]; [26] Legodi and de Waal [105]; [27] Lewis and Farmer [108]; [28] Bahçeli et al. [7]; [29] Legodi and de Waal [106]; [30] Müller et al. [122].

a With indication of the relative intensity/configuration of the observed bands ( $\mathrm{vs}=$ very strong, $\mathrm{s}=\mathrm{strong}, \mathrm{m}=\mathrm{medium}, \mathrm{w}=\mathrm{weak}, \mathrm{b}=\mathrm{broad}, \mathrm{sp}=\mathrm{sharp}$ ).

b Mineralogical phase intimately associated with the iron oxides/hydroxides that composed the ferruginous mineralisations under investigation, but in very less and subordinate amounts.

c Ascribed to the presence of $\mathrm{NO}_{3}^{-}$ions (see text).

d Mineralogical phase identified only by micro-Raman and/or FTIR. 


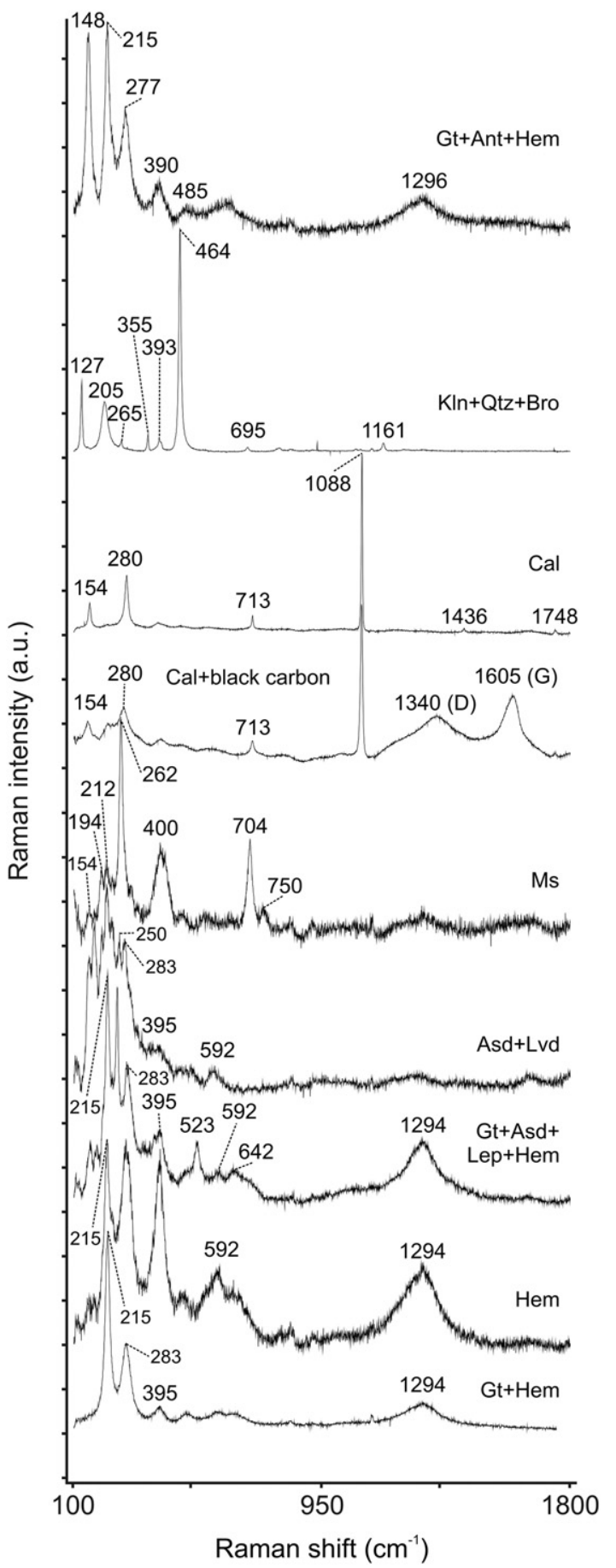

Fig. 6. Representative micro-Raman spectra in the $100-1800 \mathrm{~cm}^{-1}$ spectra region that were recorded for the sampled ferruginous mineralisations under investigation. The mineral abbreviations are the same as in Siivola and Schmid [147]. The D and G are the bands of carbonaceous materials (see text).

process. This idea is supported by the ATR-FTIR spectra, which did not present this spectral feature (Fig. 7). The intensity of the $1385 \mathrm{~cm}^{-1}$ band progressively increased from Pregrotta to Sala dei pipistrelli before decreasing and then completely disappearing in the Cunicoli terminali, which clearly matches the spatial distribution of bat guano that was observed during the field work.

In more detail, the spatially arranged average mineral assemblages of all the analysed ferruginous mineralisations are listed in Table 2 in order of relative abundance.
The crystallinity of goethite in terms of its crystal size distribution (sensu $[87,146]$ ) was semi-quantified through observations of all the $\mathrm{X}$-ray line profiles. A simple graphical comparison (after subtracting the instrumental broadening) between the measured XRD data and the crystalline standard synthetic minerals (with the most intense reflections at $\mathrm{d}_{110}=4.18 \AA \mathrm{d}_{111}=2.45 \AA$ and $\mathrm{d}_{130}=2.69 \AA$ ) from the RRUFF database (ID = R120086; last access March 2016) was used to quantify the broadening of the line profiles that are normally used for particle size distribution. XRD analysis showed that the crystallinity of the goethite in all the sub-samples was predominantly poor, sometimes even corresponding to an X-ray amorphous phase. Additionally, lepidocrocite, when present, showed broad reflections, which suggests a small average crystalline size. The relatively best crystallinity was observed on goethite from the Sala dei pipistrelli-Cunicoli terminali transition zone and Cunicoli terminali, and a few samples from the Grotta del Tesauro (as shown by relatively more intense and sharp reflections at $\mathrm{d}_{110}=4.18 \AA$ at 21.27 of $2 \theta$ and $\mathrm{d}_{111}=2.45 \AA$ at 36.71 of $2 \theta$, with minor broadening). Relatively moderately crystalline goethite was observed in the majority of sub-samples from Pregrotta. The rest of the sub-samples showed poorly crystalline or amorphous goethite/ lepidocrocite.

\subsection{Principal Component and Hierarchical Cluster Analyses}

The majority of the field samples were a mixture of minerals, including iron oxides/hydroxides, so a two-tailed Pearson's correlation test was performed to discriminate the chemical elements that were positively, negatively, or not correlated with Fe before exploring the pXRF results through multivariate statistics. Pearson's correlation coefficient was statistically analysed at a significance level of $\mathrm{P}<0.05$ and $\mathrm{P}<0.01$ (see supplementary materials - Table S3). Only the elements that were positively correlated with Fe in the Pearson's analysis (in this case, $\mathrm{Ba}, \mathrm{Cr}, \mathrm{Cs}, \mathrm{Te}, \mathrm{V}, \mathrm{W}$ and $\mathrm{Zn}$ ) were assumed to be closely related to the origin of the iron minerals, which is henceforth referred to as the local iron oxides'/hydroxides' "signature" of the sampled materials. The elements that were negatively ( $\mathrm{Ca}, \mathrm{Mg}$, $\mathrm{Pb}, \mathrm{Sb}, \mathrm{Sc}, \mathrm{S}$ and $\mathrm{Sr}$ ) or not correlated ( $\mathrm{Ag}, \mathrm{Al}, \mathrm{As}, \mathrm{Cl}, \mathrm{Co}, \mathrm{Cu}, \mathrm{K}, \mathrm{Mn}, \mathrm{Mo}, \mathrm{Nb}, \mathrm{Ni}, \mathrm{Rb}, \mathrm{Si}$, Sn, Ti and $\mathrm{Zr}$ ) with $\mathrm{Fe}$ were associated with other subordinate matrix minerals that comprised these ferruginous mineralisations or were elements that replaced Fe in the mineral's crystalline structure. The composition of the iron oxides'/ hydroxides' "signature" was considered to be independent of the matrix minerals and its pattern characteristic of a specific geological source. Determining this elemental signature is also essential for the prospective establishment of provenances when geochemical data from similar archaeological materials are available.

PCA was performed on the geochemical dataset for the following selected $\log _{10}$ Fe-normalised elements (i.e., the variables): $\mathrm{Ag}, \mathrm{Al}, \mathrm{As}, \mathrm{Ba}$, $\mathrm{Ca}, \mathrm{Cl}, \mathrm{Cr}, \mathrm{Cs}, \mathrm{Cu}, \mathrm{K}, \mathrm{Mo}, \mathrm{Pb}, \mathrm{Sb}, \mathrm{Si}, \mathrm{S}, \mathrm{Sr}, \mathrm{Te}, \mathrm{V}$ and $\mathrm{Zn}$. The choice of this lower number of elements was based on their measurement reliability in the majority of the 81 analysed sub-samples (i.e., above the detection limits) and the previous consideration that several of these elements were established as those that define the local iron oxides'/hydroxides' "signature", while others were associated with the matrix minerals; both permitted differentiation between local geochemical groups. Additional PCA scores were recalculated to include all the elements that were measured by pXRF, where the subsamples with highly anomalous elemental concentration values were included as supplementary data, to verify the reliability of the applied multivariate statistics. No significant differences were observed in either PCA.

The PCA results of 19 geochemical variables from 81 ferruginous mineralisation sub-samples are shown in Table 3. The first 4 PCA vectors constitute $76 \%$ of the total dataset variability. Among the available combinations, PC2 vs. PC3 and PC2 vs. PC4 were plotted in bivariate spaces and are used here as the representative examples of all the PC plots because they are the components that described the elements that most 

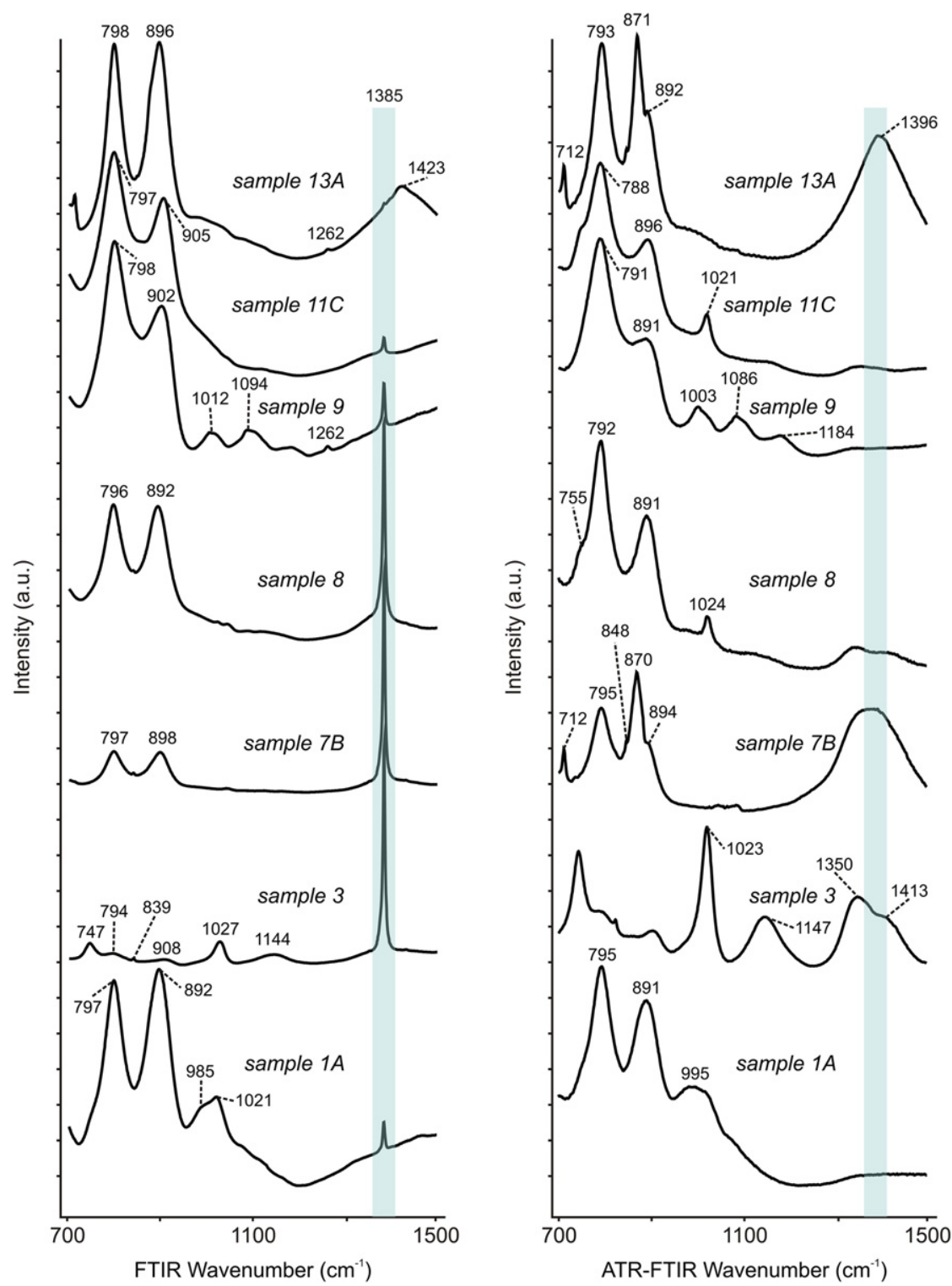

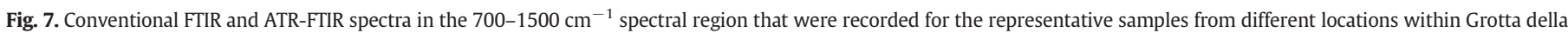

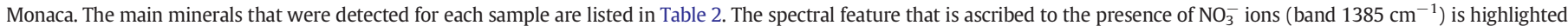
in the conventional FTIR spectra, as is its absence in the ATR-FTIR spectra (see text). The selected sampling sites are spatially indicated in Fig. 2.

clearly controlled the variance across the dataset. An examination of the PC results/plots (Table 3 and Fig. 8 ) reveals that the elements that positively affected the variance for PC2 were $\mathrm{Cu}$ and $\mathrm{Zn}$, while those that negatively affected the variance were $\mathrm{Al}$ and $\mathrm{K}$. In turn, the elements that positively affected the variance for PC3 were V, Ca and Mo, while those that negatively affected the variance were $\mathrm{As}, \mathrm{S}$ and $\mathrm{Pb}$. The elements that positively affected the variance for PC4 were $\mathrm{Si}$, Cu and $\mathrm{Al}$, while the element that negatively affected the variance was $\mathrm{Cl}$. As expected, Fig. 8 shows that the elements that belong to the same group in the periodic table often point in the same direction (e.g., $\mathrm{Ag}$ and $\mathrm{Cu}$; As and $\mathrm{Sb} ; \mathrm{Cr}$ and $\mathrm{V}$ ) because they have similar chemical and physical properties. Hence, the elements with the longest vectors into the PC spaces of Fig. 8, such as $\mathrm{Al}, \mathrm{As}, \mathrm{Cl}, \mathrm{Cu}, \mathrm{K}, \mathrm{Si}$, V, and Zn, provided better discrimination among the analysed sub-samples.

The elements with the greatest variance in the dataset were plotted in all possible combinations as a scatterplot matrix (Fig. 9) to investigate which pairs of $\log _{10}$ Fe-normalised elements could separate groups within the sampled ferruginous mineralisations.
In addition, a dendrogram of the HCA is shown in Fig. 10a. The phenon line was defined with a distance of 2 , by which all the sub-samples were classified into three statistically significant clusters.

\section{Discussion}

\subsection{Geochemical and Mineralogical Fingerprints}

The PCA indicated that an alkaline-earth metal $(\mathrm{K})$, three transition metals ( $\mathrm{Cu}, \mathrm{V}$ and $\mathrm{Zn}$ ), another metal ( $\mathrm{Al}$ ), two metalloids (As and $\mathrm{Si}$ ) and a halogen $(\mathrm{Cl})$ were the chemical elements that contributed to the variance across the sampled ferruginous mineralisations. Cornell and Schewertmann [29] suggested that some or all transition metals may substitute into the $\mathrm{Fe}^{3+}$ oxide lattice, thus leading to signatures in iron oxide/hydroxide minerals that are characteristic of a specific source. According to others authors $[80,112,128]$, transition metals (and rare earth elements) are generally positively correlated with Fe; however, the correlation is small and not statistically significant, as in 
Table 2

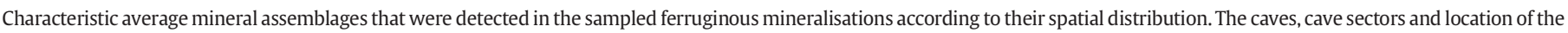
field sample are spatially indicated in Figs. 1 and 2. The mineral abbreviations are the same as in Siivola and Schmid [147].

\begin{tabular}{|c|c|c|c|c|}
\hline \multicolumn{3}{|l|}{ Cave and cave-sector } & \multirow{2}{*}{$\begin{array}{l}\text { Field sample code } \\
\text { GM1.1 }\end{array}$} & \multirow{2}{*}{$\begin{array}{l}\text { Average mineral assemblages } \\
\text { Gt (with small quantities of Asd }+ \text { Cal }+ \text { Hem }+ \text { Mgh }+ \text { organic matter) }\end{array}$} \\
\hline \multirow[t]{24}{*}{ Grotta della Monaca } & Pregrotta (PRE) & Initial & & \\
\hline & & & $1 \mathrm{~A}$ & Lep + Gt + Ms (with small quantities of Hem + Asd) \\
\hline & & & 1B & Gt (with small quantities of Hem + Asd) \\
\hline & & & 1C & Gt (with small quantities of Hem + Asd) \\
\hline & & & 2 & Gt (with small quantities of Hem + Asd) \\
\hline & & & 3 & Lep + Gt + Ms (with small quantities of Asd + Lvd + organic matter) \\
\hline & & Middle & 4 & Lep $+\mathrm{Gt}$ (with small quantities of Hem + Asd + Cal) \\
\hline & & & 5 & $\mathrm{Gt}+\mathrm{Gp}+\mathrm{Cal}$ (with small quantities of Asd) \\
\hline & & Final & $6 \mathrm{~A}$ & Gt + Lep (with small quantities of Asd) \\
\hline & & & $6 B$ & $\mathrm{Gt}+\mathrm{Cal}+\mathrm{Lep}+\mathrm{Gp}($ with small quantities of Hem + Asd $)$ \\
\hline & Sala dei pipistrell & & $7 \mathrm{~A}$ & $\mathrm{Gt}+\mathrm{Cal}+\mathrm{Gp}+\mathrm{Ms}$ (with small quantities of Asd + Lvd + Ant + Bro + Qtz) \\
\hline & & & $7 \mathrm{~B}$ & $\mathrm{Gt}+$ Cal + Ms (with small quantities of Asd + Lvd + organic matter) \\
\hline & & & 8 & Gt + Ms (with small quantities of Asd + Lvd + organic matter) \\
\hline & & & GM4.3 & Gt (with small quantities of Asd $+\mathrm{Hem}+\mathrm{Ms}$ ) \\
\hline & & & 9 & Gt (with small quantities of Asd + Lvd + organic matter) \\
\hline & & & 10 & Gt (with small quantities of Asd) \\
\hline & & & $11 \mathrm{~A}$ & Gt (with small quantities of Asd + Lvd) \\
\hline & & & 11B & Gt (with small quantities of Asd + Hem + Lvd) \\
\hline & & & $11 C$ & Gt + Ms (with small quantities of Asd + Lvd + organic matter) \\
\hline & & & 12 & $\mathrm{Gt}+\mathrm{Qtz}+\mathrm{I}$ (with small quantities of Asd + Hem + Lvd + Ms) \\
\hline & Cunicoli terminal & & $13 \mathrm{~A}$ & $\mathrm{Gt}+\mathrm{Cal}+\mathrm{Kln}+\mathrm{I}$ (with small quantities of Asd $+\mathrm{Hem})$ \\
\hline & & & $13 \mathrm{~B}$ & $\mathrm{Gt}+\mathrm{Cal}+\mathrm{Kln}+\mathrm{I}$ (with small quantities of Asd $+\mathrm{Hem})$ \\
\hline & & & 14 & $\mathrm{Gt}+\mathrm{Lm}+\mathrm{Kln}+\mathrm{I}$ (with small quantities of Asd + Ant) \\
\hline & & & 15 & Gt + Cal + Kln + I (with small quantities of Asd + Hem) \\
\hline \multirow[t]{3}{*}{ Grotta del Tesauro } & (TES) & & GT2.1 & $\mathrm{Gt}+\mathrm{Gp}+\mathrm{K} \ln$ (with small quantities of Hem + Asd $+\mathrm{Ms}$ ) \\
\hline & & & GT7.1 & $\mathrm{Gt}+\mathrm{Gp}+\mathrm{Kln}+\mathrm{Cal}$ (with small quantities of Hem + Lvd) \\
\hline & & & GT7.2 & Gt + Kln (with small quantities of Hem + Asd + Mgh) \\
\hline
\end{tabular}

this case (see Table S3). Therefore, $\mathrm{Al}$, Si and $\mathrm{K}$ are most probably linked to the clay minerals (kaolinite and illite) and/or the other silicates (quartz and muscovite) that comprised the analysed materials in the sampled ferruginous mineralisations, while $\mathrm{V}$ and $\mathrm{Zn}$ are likely associated with the iron oxides'/hydroxides' "signature". $\mathrm{As}, \mathrm{Cu}$ and $\mathrm{Cl}$ are probably associated with the detected arsenates (arsenosiderite and lavendulan).

The bivariate plots of $\log _{10}[\mathrm{As} / \mathrm{Fe}]$ vs. all other $\log _{10}$ Fe-normalised chosen elements show patterns in the data trend with some of the clearest distinctions between the sampled mineralisations (Fig. 9). Although some overlaps exist, most of the sub-sample sets that were identified by the confidence ellipses (drawn where the sub-sample numbers were statistically significant) formed distinct groups. The sub-samples from Pregrotta were widely distributed in the majority of these specific

Table 3

Principal component matrix results on selected $\log _{10}$ Fe-normalised variables. The data that are shown in bold indicate relative and absolute higher loading and their contribution to their respective components.

\begin{tabular}{lllll}
\hline Variable & PC1 & PC2 & PC3 & PC4 \\
\hline $\mathrm{Sr}$ & $\mathbf{0 . 8 1}$ & 0.01 & 0.39 & -0.09 \\
$\mathrm{~Pb}$ & $\mathbf{0 . 8 0}$ & 0.10 & $-\mathbf{0 . 4 4}$ & -0.06 \\
$\mathrm{Cs}$ & $\mathbf{0 . 7 8}$ & 0.13 & -0.20 & 0.01 \\
$\mathrm{Cr}$ & $\mathbf{0 . 7 8}$ & -0.08 & 0.28 & 0.03 \\
$\mathrm{Ca}$ & $\mathbf{0 . 7 6}$ & -0.11 & $\mathbf{0 . 4 7}$ & -0.29 \\
$\mathrm{Sb}$ & $\mathbf{0 . 7 4}$ & 0.43 & -0.39 & -0.12 \\
$\mathrm{~S}$ & 0.66 & -0.29 & $-\mathbf{0 . 4 3}$ & -0.26 \\
$\mathrm{Te}$ & 0.66 & 0.09 & -0.27 & -0.07 \\
$\mathrm{~V}$ & 0.65 & -0.24 & $\mathbf{0 . 4 8}$ & 0.03 \\
$\mathrm{Ag}$ & 0.63 & 0.56 & -0.03 & 0.29 \\
$\mathrm{Cl}$ & 0.62 & -0.26 & 0.28 & $-\mathbf{0 . 5 1}$ \\
$\mathrm{As}$ & 0.57 & 0.46 & $-\mathbf{0 . 4 6}$ & 0.17 \\
$\mathrm{Al}$ & 0.25 & $-\mathbf{0 . 8 1}$ & -0.05 & $\mathbf{0 . 4 1}$ \\
$\mathrm{Cu}$ & -0.04 & $\mathbf{0 . 7 3}$ & 0.23 & $\mathbf{0 . 5 1}$ \\
$\mathrm{K}$ & 0.54 & $-\mathbf{0 . 7 3}$ & -0.03 & 0.32 \\
$\mathrm{Zn}$ & 0.27 & $\mathbf{0 . 6 8}$ & 0.22 & 0.12 \\
$\mathrm{Mo}$ & 0.03 & 0.55 & $\mathbf{0 . 4 2}$ & -0.29 \\
$\mathrm{Ba}$ & 0.23 & 0.54 & 0.18 & 0.34 \\
$\mathrm{Si}$ & 0.44 & -0.51 & 0.18 & $\mathbf{0 . 6 3}$ \\
Eigenvalue (\%) & 35.44 & 21.10 & 10.40 & 8.92 \\
Cumulative (\%) & 35.44 & 56.54 & 66.94 & 75.87 \\
\hline
\end{tabular}

bivariate plots, while most of them formed a group in the centre of the bivariate space. The sub-samples from the Cunicoli terminali always showed few cases of dispersion into bivariate space, with one subgroup corresponding to materials with extremely low concentrations of Fe and As and a higher concentration of Ca, which are more closely associated with sub-samples from Grotta del Tesauro and Pregrotta than the sub-samples from Sala dei pipistrelli. In contrast, most of the subsamples from Sala dei pipistrelli and Grotta del Tesauro formed individualised and distinct groups. Among all the bivariate scatterplots in Fig. 9, arsenic [As/Fe] and copper $[\mathrm{Cu} / \mathrm{Fe}]$ were the elements that could primarily be used to identify inter-cave variations and some intra-cave differences (even if not always clearly evident). The scatterplot of $\log _{10}[\mathrm{Cu} / \mathrm{Fe}] \mathrm{vs} . \log _{10}[\mathrm{As} / \mathrm{Fe}]$ provides an example of the range of pair elements that demonstrated grouping. The main groups of sub-samples could be distinguished from each other according to their original geomorphological contexts by using these specific element pair ratios, where the relationship between cave sectors that belong to the same group agrees with their relatively close spatial proximity.

The three recognised geochemical clusters often matched their broad location within Grotta della Monaca (i.e., intra-cave variations). Cluster I consists of samples that were mainly collected near the entrance of Grotta della Monaca, in the final area of Cunicoli terminali, and in Grotta del Tesauro. Most of the samples in Cluster II were in the initial-middle portions of Pregrotta and Sala dei pipistrelli. Cluster III often includes samples from the Sala dei pipistrelli-Cunicoli terminali transition zone and a few sub-samples from the final area of Pregrotta. Furthermore, all the sub-samples from the three clusters that were obtained by HCA were allocated in a bivariate scatterplot according to their PCA scores to represent the relative importance of the PCs in different clusters (Fig. 10b). Clusters I and II showed PC1 values $<2$, while Cluster III showed the opposite, which indicates some similarities between the first two groups according to the amount of Fe vs. all other element concentrations.

The minimum, maximum, mean-values, standard deviation and coefficient of variation of the geochemical elements (variables) are presented to quantify the variation between clusters and summarise the characteristics of the sub-samples in each cluster (Table 4). Despite 

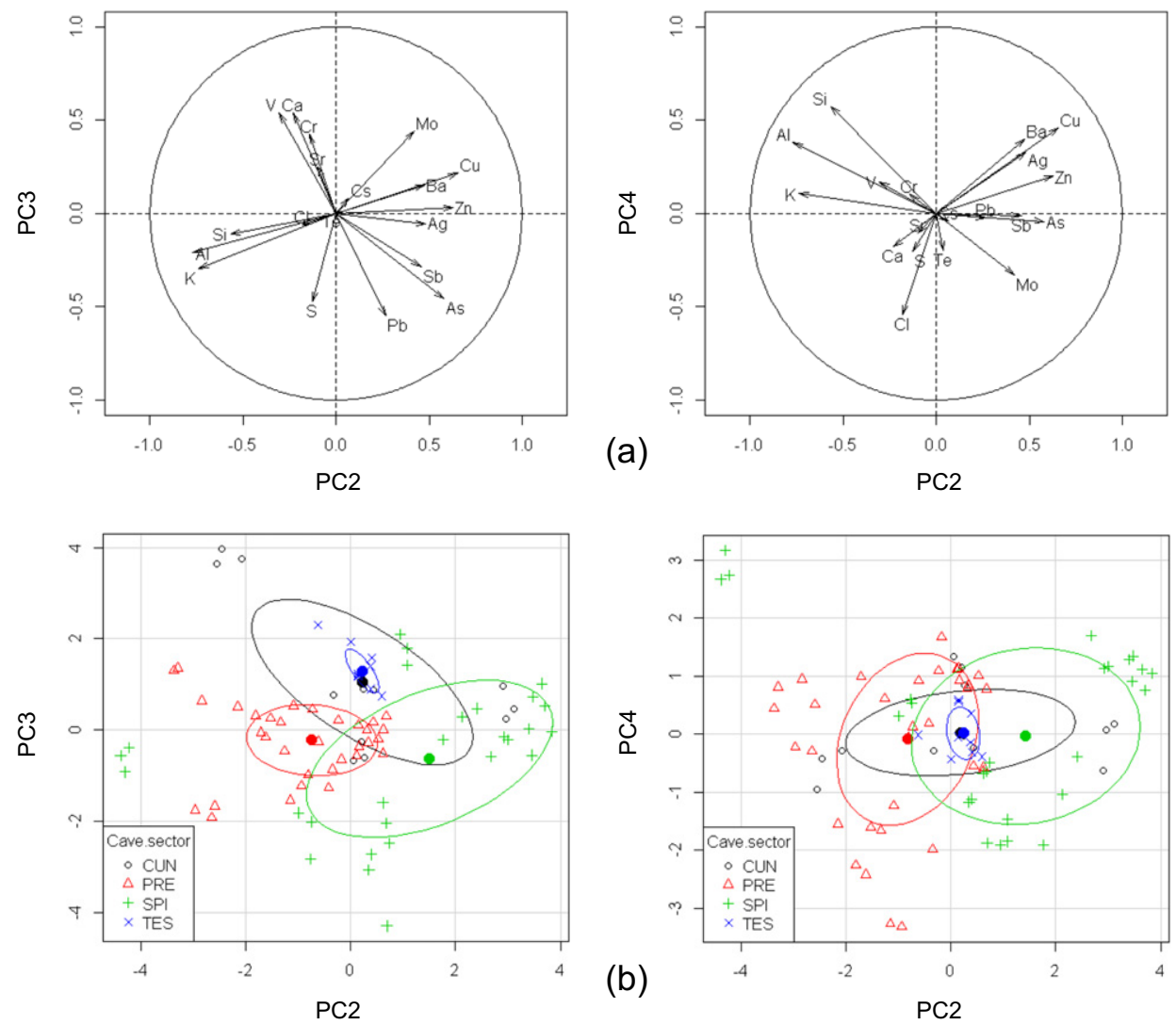

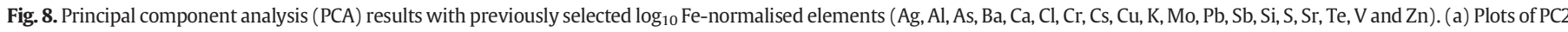

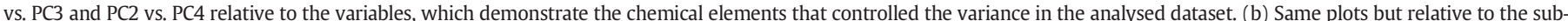

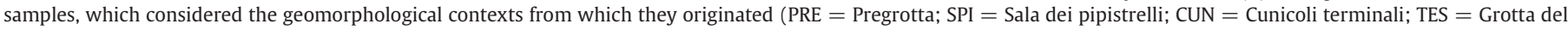
Tesauro), demonstrating the dispersion of the groups. Confidence ellipses were drawn with a concentration level of 0.5 to better visualise the geochemical patterns or groups.

several high standard deviations values and few coefficients of variation greater than one (indicating high variance), major differences exist between the averages of the selected elements. Thus, the sampled ferruginous mineralisations within the studied caves display the highest mean Fe concentrations in Cluster I (56.2\%) and the lowest values in Cluster III (36.1\%). The $\mathrm{Ca}, \mathrm{Cu}$ and $\mathrm{Mg}$ concentrations are higher in Cluster III than those in Clusters I and II, with relative mean values of $11.5 \%, 1.3 \%$ and $1.5 \%$, respectively. The sampled mineralisations in Cluster II are characterised by relatively higher $\mathrm{Al}, \mathrm{K}, \mathrm{Si}$ and $\mathrm{S}$ concentrations compared to those in Clusters I and III, with mean values of $0.8 \%, 0.5 \%$, $1.2 \%$ and $0.4 \%$, respectively. The mean $\mathrm{Cu}$ concentration is much higher in Cluster I (0.5\%) than those in Clusters II and III (both 0.1\%). From a mineralogical perspective, Cluster I often consists of relatively crystalline goethite-limonite with subordinate amounts of calcite and clay minerals (kaolinite and illite), except for the sampled ferruginous mineralisations from Grotta del Tesauro, which show small quantities of gypsum. Muscovite and calcite occurred in Cluster II in addition to the ubiquitous assemblage of often poorly crystalline lepidocrocite + goethite. Cluster III often shows poorly to relatively crystalline goethite in association with calcite, gypsum, quartz and clay minerals (kaolinite and illite). The presence of poorly crystalline lepidocrocite, often in the sub-samples that comprise Cluster II, and gypsum in Cluster III and within Grotta del Tesauro could be defining mineralogical markers for the analysed materials.

These preliminary results and respective interpretations indicate that the analysed ferruginous mineralisations could be easily and quickly identified based on their elemental signature and their mineralogical assemblages. Intra-cave variations could be recognised by using PCA and HCA. Similarly, preliminary inter-cave variations were detected by using specific ranges of element pairs that were plotted in bivariate space.

\subsection{Archaeological Implications}

The archaeological implications of these findings are substantial and demonstrate specific exploitation strategies of local ferruginous mineralisations during prehistory. Indeed, the Upper Palaeolithic extractive phase was recognised exclusively in the Pregrotta and is the most evanescent compared to the Late Neolithic and post-Medieval phases, documented only in a very restricted mining area (near the cave entrance) by fleeting archaeological evidence. Palaeolithic mining evidence is likely more common and spatially extended; however, these were largely destroyed because of subsequent human frequentations and especially after strong and intensive post-Medieval exploitation. The available varieties of ferruginous mineralisations were likely not specifically chosen during the Upper Palaeolithic; rather, material that was well-exposed and visible within the Pregrotta was utilized. The abundant ferruginous mineralisations that are exposed at the cave entrance, which have bright yellow-orange to red chromatism, most likely attracted the attention of Upper Palaeolithic human groups in transit along the Esaro Valley. The Late Neolithic extractive phase was documented in several areas of Grotta della Monaca, although the most important evidence originated from the Sala dei pipistrelliCunicoli terminali transition zone, which showed the highest $\mathrm{Cu}$ concentrations in the exploited massive ferruginous mineralisations (consisting of the most crystalline goethite in association with clay minerals, which confer high plasticity). The Late Neolithic miners struck the outcrops of ferruginous mineralisations with picks that were constructed from deer antlers and other tools (hoes, palettes and awls) from the bones of large mammals (e.g., [94]). Generally, their attention was directed to a particular facies of ferruginous mineralisations: the yelloworange and soft goethite-rich varieties (constantly wet because of the 


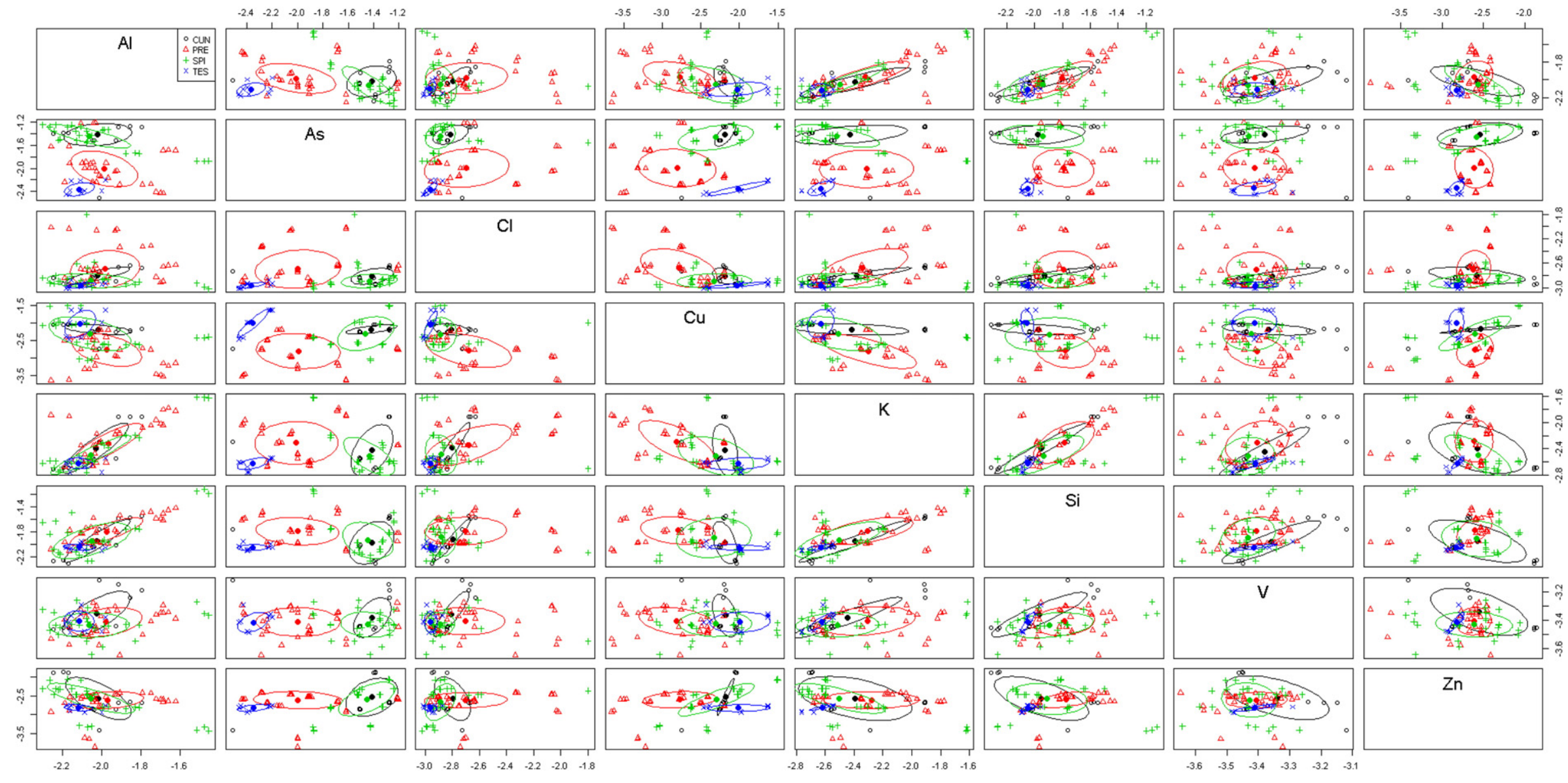

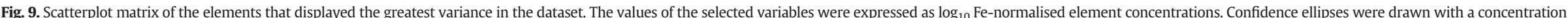

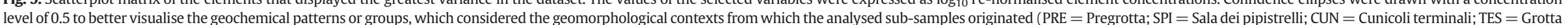
del Tesauro). Additionally, a bivariate plot of $\log _{10}[\mathrm{As} / \mathrm{Fe}]$ vs. all other $\log _{10} \mathrm{Fe}$-normalised elements demonstrates the dispersion of the groups. 

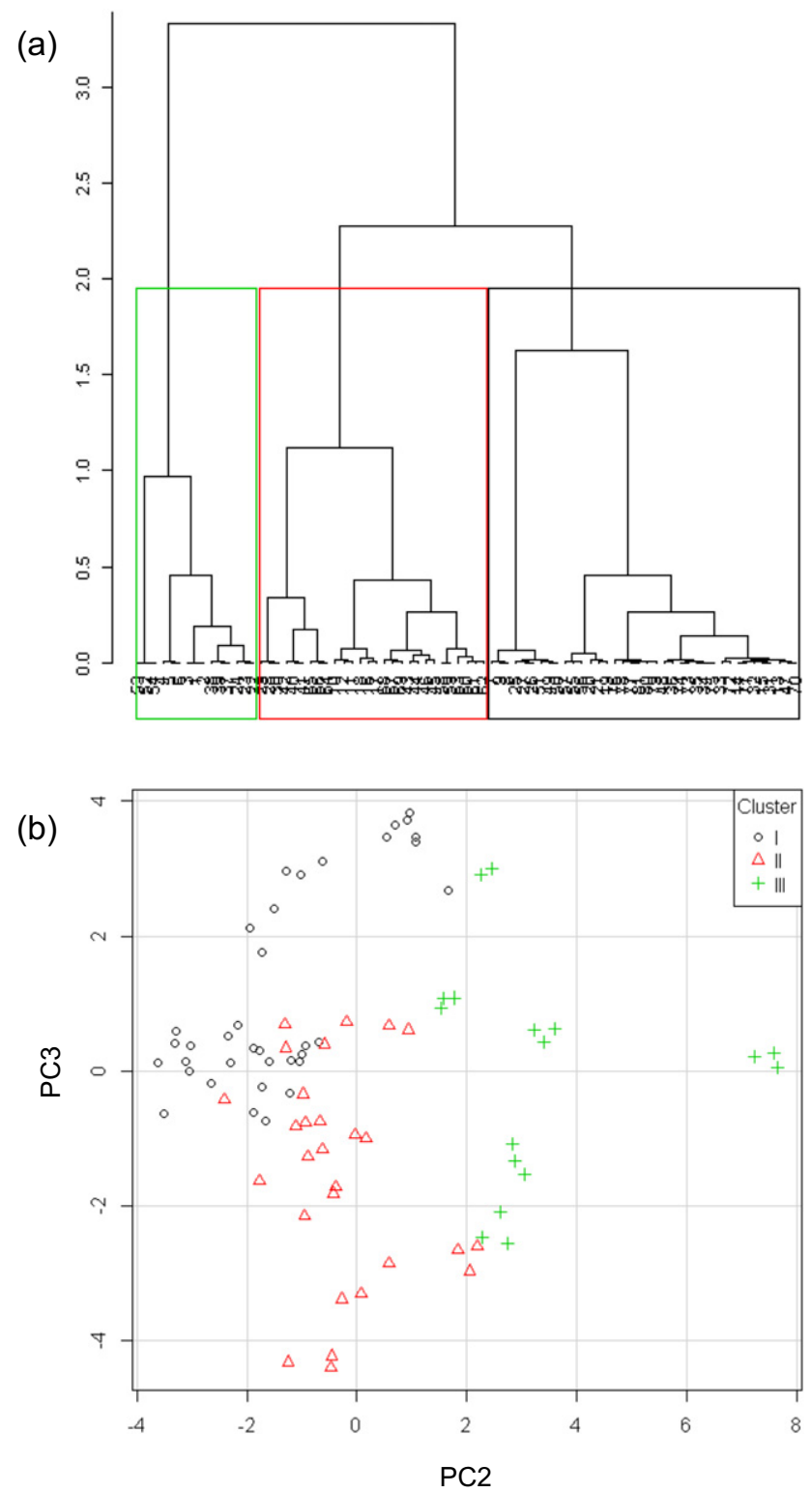

Fig. 10. Hierarchical clustering analysis (HCA) results. (a) Dendrogram for all the analysed sub-samples. (b) Distribution of sub-samples according to three statistically significant clusters.

very specific local environmental cave conditions), which were easily identified in the outcrops and mouldable with even minimal pressure on the surface. The interest of this specific variety of ferruginous mineralisation from Late Neolithic miners is demonstrated by two findings: (1) the hundreds of digging traces that are still preserved on the related survivor's mineralisations, and (2) the disposal of the most compact and reddish-brown fragments/blocks (i.e., mining wastes) as artificial stonewalls that were erected in the exploitation areas. Even during the post-Medieval mining phase, ferruginous mineralisations that appeared to be more massive and soft were extracted along two artificial galleries that were excavated under the ground of the Pregrotta and Sala dei pipistrelli, while more compact and less malleable materials were discarded and used to build stonewalls (together with carbonate rocky blocks and fragments).

The specific uses of these extracted ferruginous mineralisations from Grotta della Monaca and Grotta del Tesauro are currently unknown, as are the destinations of these mineral resources.

\section{Conclusions}

This study provided preliminary geochemical and mineralogical characterisations of the well-exposed ferruginous mineralisations from Grotta della Monaca (including some evidence from the nearby Grotta del Tesauro) by using a combination of techniques, such as pXRF, XRD, micro-Raman and FTIR. Subsequently, multivariate statistics on selected elemental concentration data enabled us to identify the elements that controlled the variance, which were displayed in bivariate plots. Among these factors, the $[\mathrm{As} / \mathrm{Fe}]$ and $[\mathrm{Cu} / \mathrm{Fe}]$ ratios provided a clear and unambiguous distinction between the ferruginous mineralisations from the two caves and among spatially distant cave sectors.

Even if the oxides/hydroxides and related matrix mineral assemblages were determined for each sample/sub-sample and few differences were detected between them (e.g., presence/absence of lepidocrocite and gypsum, along with few differences in the crystallinity of goethite), a quantitative comparison that was based only on their mineralogy would be impossible from a mineralogical perspective. XRD provided qualitative information on the mineralogy of the analysed materials, but the presence and identification of mineralogical phases alone were insufficient to differentiate between groups. XRD, microRaman and FTIR provided both mineralogical and crystallographic information, but their inability to quantify the minerals made relating the phases to the elemental concentrations that were obtained by pXRF difficult. However, combining these methodologies enabled us to overcome some of these limitations.

Both PCA and HCA on selected geochemical datasets demonstrated that the sampled ferruginous mineralisations statistically formed three clusters with unique elemental signatures. As expected, the identified clusters, each one with very specific geochemical-mineralogical "fingerprints" and spatial distributions, enabled us to identify the sampled ferruginous mineralisations. These specific mineral resources could be compared to similar raw materials in other neighbouring archaeological sites, with obvious implications in understanding the local exploitation strategies through time and the exchanges and kinship networks of these materials. From a geochemical and mineralogical prospective, these three clusters showed distinct differences in their Fe and As contents and in the matrix mineral assemblage, which may represent spatial variations in local geologic conditions, including diagenetic processes (e.g., the oxidation of primary sulphides in the carbonate bedrock and the concomitant and/or subsequent precipitation of other secondary cave minerals).

Handheld portable X-ray Fluorescence spectroscopy was a rapid and inexpensive alternative to laboratory-based geochemical techniques. In this specific case, the use of pXRF was obviously insufficient to exhaustively characterise the chemistry of the sampled materials, but this approach enabled us to draw some important conclusions that ultimately should be better explained and confirmed (or eventually rejected) by applying more sophisticated and finer-resolution elemental analysis techniques. From this perspective, choosing which groups of chemical elements from the periodic table should be subject to a more precise and detailed quantification with other more robust and, eventually, precise techniques, such as instrumental neutron activation analysis (INAA), atomic absorption spectrophotometry and scanning electron microscopy with X-ray microanalysis (SEM + EDS), should be possible. Among these techniques, INAA seemed to be the best for measuring elements that are diagnostic for differentiating chemical groups of iron oxides/hydroxides, such as (but not limited to) transition metals and rare earth elements.

In addition, archaeological samples such as the building blocks of the stonewalls within Grotta della Monaca represent the mining wastes of the prehistoric exploitation of the local ferruginous mineralisations, which must also be characterised from a geochemical and mineralogical prospective. The results that could be obtained from these archaeological materials may provide more useful and credible information on the 
Table 4

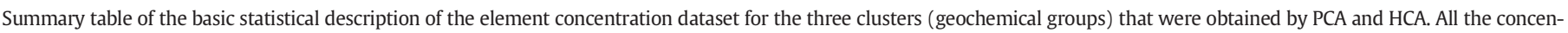

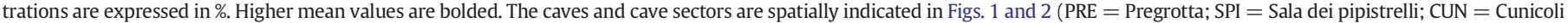
terminali; TES = Grotta del Tesauro).

\begin{tabular}{|c|c|c|c|c|c|c|c|c|c|c|c|c|c|c|c|}
\hline \multirow[t]{3}{*}{ Variable } & \multicolumn{5}{|c|}{ Cluster I $(\mathrm{n}=36)$} & & \multicolumn{5}{|c|}{ Cluster III $(\mathrm{n}=17)$} \\
\hline & \multicolumn{5}{|c|}{$\begin{array}{l}\text { TES + near the entrance of PRE + final part of } \\
\text { CUN }\end{array}$} & \multicolumn{5}{|c|}{ Initial-middle parts of PRE + SPI } & \multicolumn{5}{|c|}{ SPI-CUN transition zone + final part of PRE } \\
\hline & Min. & Max. & Mean & St. dev. & $\mathrm{CV}$ & Min. & Max. & Mean & St. dev. & $\mathrm{CV}$ & Min. & Max. & Mean & St. dev. & $\mathrm{CV}$ \\
\hline $\mathbf{F e}(\%)$ & 48.754 & 61.777 & 56.230 & \pm 3.635 & 0.065 & 45.049 & 59.323 & 53.418 & \pm 4.621 & 0.086 & 25.140 & 48.819 & 36.149 & \pm 8.336 & 0.231 \\
\hline $\mathrm{Ag}$ & 0.001 & 0.026 & 0.004 & \pm 0.005 & 1.268 & 0.001 & 0.003 & 0.002 & \pm 0.001 & 0.517 & 0.001 & 0.028 & 0.008 & \pm 0.009 & 1.049 \\
\hline Al & 0.289 & 0.639 & 0.449 & \pm 0.094 & 0.210 & 0.301 & 1.678 & 0.784 & \pm 0.365 & 0.465 & 0.245 & 0.482 & 0.353 & \pm 0.134 & 0.379 \\
\hline As & 0.207 & 2.818 & 1.225 & \pm 0.975 & 0.796 & 0.165 & 2.640 & 1.071 & \pm 0.796 & 0.743 & 0.079 & 2.804 & 1.294 & \pm 0.971 & 0.751 \\
\hline $\mathrm{Ba}$ & 0.020 & 0.234 & 0.065 & \pm 0.053 & 0.816 & 0.017 & 0.063 & 0.034 & \pm 0.012 & 0.348 & 0.014 & 0.051 & 0.032 & \pm 0.012 & 0.380 \\
\hline Ca & 0.143 & 9.053 & 1.522 & \pm 2.359 & 1.551 & 0.079 & 12.449 & 2.209 & \pm 3.599 & 1.629 & 1.289 & 21.562 & 11.529 & \pm 6.433 & 0.558 \\
\hline $\mathrm{Cl}$ & 0.055 & 0.829 & 0.092 & \pm 0.127 & 1.381 & 0.046 & 0.520 & 0.145 & \pm 0.145 & 1.000 & 0.047 & 0.361 & 0.120 & \pm 0.109 & 0.905 \\
\hline Co & 0.078 & 0.109 & 0.091 & \pm 0.032 & 0.355 & 0.071 & 0.122 & 0.095 & \pm 0.040 & 0.425 & 0.066 & 0.066 & 0.066 & \pm 0.016 & 0.243 \\
\hline $\mathrm{Cr}$ & 0.051 & 0.073 & 0.063 & \pm 0.006 & 0.094 & 0.050 & 0.068 & 0.058 & \pm 0.005 & 0.088 & 0.041 & 0.064 & 0.053 & \pm 0.008 & 0.141 \\
\hline Cs & 0.009 & 0.018 & 0.012 & \pm 0.002 & 0.164 & 0.009 & 0.016 & 0.012 & \pm 0.002 & 0.158 & 0.008 & 0.014 & 0.011 & \pm 0.002 & 0.164 \\
\hline $\mathrm{Cu}$ & 0.186 & 1.655 & 0.549 & \pm 0.426 & 0.775 & 0.012 & 0.382 & 0.091 & \pm 0.083 & 0.919 & 0.041 & 0.409 & 0.125 & \pm 0.115 & 0.920 \\
\hline $\mathbf{K}$ & 0.097 & 0.301 & 0.137 & \pm 0.042 & 0.305 & 0.156 & 1.158 & 0.489 & \pm 0.308 & 0.630 & 0.103 & 0.329 & 0.190 & \pm 0.088 & 0.462 \\
\hline Mg & 0.885 & 1.188 & 1.078 & \pm 0.476 & 0.441 & 0.985 & 1.881 & 1.369 & \pm 0.504 & 0.368 & 1.128 & 2.056 & 1.491 & \pm 0.675 & 0.453 \\
\hline $\mathrm{Mn}$ & n.d. & n.d. & & & & 0.020 & 0.049 & 0.032 & \pm 0.013 & 0.412 & n.d. & n.d. & & & \\
\hline Mo & 0.001 & 0.006 & 0.003 & \pm 0.002 & 0.554 & 0.001 & 0.004 & 0.002 & \pm 0.001 & 0.476 & 0.001 & 0.008 & 0.003 & \pm 0.002 & 0.838 \\
\hline $\mathrm{Nb}$ & n.d. & n.d. & & & & 0.001 & 0.001 & 0.001 & \pm 0.000 & 0.189 & n.d. & n.d. & & & \\
\hline $\mathrm{Ni}$ & n.d. & n.d. & & & & n.d. & n.d. & & & & 0.009 & 0.016 & 0.012 & \pm 0.006 & 0.528 \\
\hline $\mathrm{Pb}$ & 0.005 & 0.130 & 0.038 & \pm 0.035 & 0.922 & 0.004 & 0.327 & 0.124 & \pm 0.125 & 1.013 & 0.005 & 0.623 & 0.203 & \pm 0.204 & 1.005 \\
\hline $\mathrm{Rb}$ & 0.001 & 0.001 & 0.001 & \pm 0.000 & 0.440 & 0.000 & 0.001 & 0.001 & \pm 0.000 & 0.544 & 0.000 & 0.001 & 0.001 & \pm 0.000 & 0.523 \\
\hline $\mathrm{Sb}$ & 0.005 & 0.100 & 0.027 & \pm 0.027 & 1.015 & 0.004 & 0.086 & 0.033 & \pm 0.030 & 0.912 & 0.003 & 0.100 & 0.055 & \pm 0.035 & 0.635 \\
\hline Sc & n.d. & n.d. & & & & 0.009 & 0.009 & 0.009 & \pm 0.002 & 0.189 & 0.025 & 0.060 & 0.037 & \pm 0.019 & 0.514 \\
\hline $\mathbf{S i}$ & 0.274 & 1.559 & 0.641 & \pm 0.302 & 0.472 & 0.313 & 3.612 & 1.185 & \pm 0.897 & 0.757 & 0.366 & 1.126 & 0.611 & \pm 0.220 & 0.360 \\
\hline Sn & 0.004 & 0.010 & 0.008 & \pm 0.003 & 0.364 & 0.006 & 0.006 & 0.006 & \pm 0.001 & 0.189 & 0.004 & 0.012 & 0.007 & \pm 0.004 & 0.576 \\
\hline$S$ & 0.030 & 0.230 & 0.105 & \pm 0.051 & 0.487 & 0.056 & 1.208 & 0.409 & \pm 0.375 & 0.916 & 0.072 & 1.156 & 0.339 & \pm 0.391 & 1.154 \\
\hline $\mathrm{Sr}$ & 0.001 & 0.008 & 0.004 & \pm 0.002 & 0.527 & 0.001 & 0.008 & 0.005 & \pm 0.003 & 0.533 & 0.005 & 0.012 & 0.009 & \pm 0.002 & 0.259 \\
\hline $\mathrm{Te}$ & 0.011 & 0.026 & 0.017 & \pm 0.005 & 0.307 & 0.011 & 0.028 & 0.017 & \pm 0.005 & 0.309 & 0.010 & 0.020 & 0.016 & \pm 0.003 & 0.168 \\
\hline $\mathrm{Ti}$ & 0.013 & 0.013 & 0.013 & \pm 0.002 & 0.167 & 0.017 & 0.085 & 0.043 & \pm 0.028 & 0.651 & 0.019 & 0.022 & 0.021 & \pm 0.007 & 0.333 \\
\hline V & 0.015 & 0.030 & 0.021 & \pm 0.003 & 0.145 & 0.013 & 0.026 & 0.020 & \pm 0.004 & 0.186 & 0.014 & 0.023 & 0.019 & \pm 0.003 & 0.150 \\
\hline W & n.d. & n.d. & & & & n.d. & n.d. & & & & 0.012 & 0.032 & 0.022 & \pm 0.008 & 0.371 \\
\hline $\mathrm{Zn}$ & 0.068 & 0.781 & 0.214 & \pm 0.192 & 0.895 & 0.008 & 0.213 & 0.083 & \pm 0.058 & 0.707 & 0.010 & 0.236 & 0.106 & \pm 0.069 & 0.646 \\
\hline $\mathrm{Zr}$ & n.d. & n.d. & & & & 0.001 & 0.002 & 0.001 & \pm 0.001 & 0.528 & n.d. & n.d. & & & \\
\hline
\end{tabular}

$\mathrm{n}=$ Number of sub-samples that compose the cluster.

St. dev. = standard deviation.

$\mathrm{CV}=$ coefficient of variation (distributions with $\mathrm{CV}<1$ are considered low variance, while those with $\mathrm{CV}>1$ are considered high variance).

n.d. = concentrations not measured because they were below the instrument's detection limits.

local mine exploitation strategies by prehistoric peoples compared to those from geological materials.

Finally, future regional-scale studies should include quick and nondestructive pXRF analyses on yellow-orange and/or red pigments from artefacts of other nearby archaeological sites to investigate the possibility of designating the karstic caves in the Upper Esaro Valley as geological sources of their raw materials.

Supplementary data to this article can be found online at doi:10. 1016/j.saa.2016.10.021.

\section{Author Contributions}

D.L. conceived the research; D.L., R.N and P.J. designed the research; D.L and L.F. performed the field work; L.F. and his team performed previous archaeological investigations; D.L. performed and interpreted the pXRF and XRD data with the technical help of Mr. Carlos Maia; B.C.L. and A.M.A. performed and interpreted the micro-Raman and FTIR data; D.L. wrote the paper; and all the authors reviewed and edited the manuscript. Furthermore, all the authors have read and approved the manuscript, declaring no conflict of interest.

\section{Acknowledgements}

This work is a contribution to the strategic project UID/GEO/04084/ 2013, which was supported by national funds from FCT (Portuguese national funding agency for science, research and technology) and by the European fund for economic and regional development (FEDER) through the COMPETE 2020 - program operation of competitiveness and internationalisation (POCI-01-0145-FEDER-006891). The Unidade de I\&D "Química-Física Molecular" also acknowledge financial support from the FCT (strategic project UID/Multi/00070/2013). Acknowledgements are also due to Laboratório Associado CICECO, University of Aveiro (Portugal), for the ATR-FTIR spectra records. Constructive comments and suggestions by an anonymous reviewer were gratefully acknowledged.

\section{References}

[2] A. Al-Malabeh, S. Kempe, H.-V. Henschel, H. Hofmann, H.J. Tobschall, The possibly hypogene karstic iron ore deposit of Warda near Ajloun (northern Jordan), its mineralogy, geochemistry and historic mine, Acta Carsologica 37 (2-3) (2008) 241-253.

[3] L. Amodio Morelli, G. Bonardi, V. Colonna, D. Dietrich, G. Giunta, F. Ippolito, V. Liguori, S. Lorenzoni, A. Paglionico, V. Perrone, G. Piccarreta, M. Russo, P. Scandone, E. Zanettin-Lorenzoni, A. Zuppetta, L'Arco Calabro-Peloritano nell'orogene Appeninico-Maghrebide, Mem. Soc. Geol. Ital. 17 (1976) 1-60.

[4] F. Arena, F. Larocca, N. Onisto, E. Gualdi-Russo, Il sepolcreto protostorico di Grotta della Monaca in Calabria. Aspetti antropologici, Annali dell'Università di Ferrara, Museologia Scientifica e Naturalistica 10 (2) (2014) 74-80.

[5] P. Audra, J.-Y. Bigot, H. Camus, C. Gauchon, M. Wienin, La grotte-mine du Piei (Lagnes, Vaucluse), paléokarst hypogéne à remplissage de minerai de fer oxydé, Karstologia 58 (2011) 1-14

[6] P. Audra, J.-Y. Bigot, H. Camus, C. Gauchon, M. Wienin, Hypogenic speleogenesis with ferruginous ore. The Piei mine-cave (Lagnes, Vaucluse, France), Memorie Instituto Italiano di Speleologia 28 (s. II) (2013) 41-70.

[7] S. Bahçeli, G. Güleçb, H. Erdoğanb, B. Söğütc, Micro-Raman and FT-IR spectroscopic studies of ceramic shards excavated from ancient Stratonikeia city at Eskihisar village in West-South Turkey, J. Mol. Struct. 1106 (2016) 316-321. 
[8] L.S. Barham, Systematic pigment use in the Middle Pleistocene of southcentral Africa, Curr. Anthropol. 43 (2002) 181-190.

[9] M.J. Baxter, Exploratory Multivariate Analysis in Archaeology, Edinburgh University Press, Edinburgh, 1994.

[10] D. Bikiaris, S. Daniilia, S. Sotiropoulou, O. Katsimbiri, E. Pavlidou, A.P. Moutsatsou, Y. Chryssoulakis, Ochre-differentiation through micro-Raman and micro-FTIR spectroscopies: application on wall paintings at Meteora and Mount Athos, Greece, Spectrochim. Acta A Mol. Biomol. Spectrosc. 56 (1) (2000) 3-18.

[11] G. Bonardi, B. De Vivo, G. Giunta, A. Lima, A. Perrone, A. Zuppetta, Mineralizzazioni dell'Arco Calabro-Peloritano: Ipotesi genetiche e quadro evolutivo, Boll. Soc. Geol. Ital. 101 (1982) 141-155.

[12] V. Bongiorno, R. Campodonico, S. Caffara, P. Piccardo, M.M. Carnasciali, MicroRaman spectroscopy for the characterization of artistic patinas produced on copper-based alloys, J. Raman Spectrosc. 43 (11) (2012) 1617-1622.

[13] M. Boni, M. Torre, V. Zamparelli, Il Trias medio superiore dell'Unità di San Donato (Appennino Meridionale, Calabria): risultati preliminari, Rend. Soc. Geol. Ital. 13 (1990) 89-92.

[14] R. Bouchard, D. Kennedy, Squamish Indian Land Use and Occupancy, B.C. Indian Language Project, Victoria B.C., 1986

[15] S.A. Brandt, E.C. Fisher, E.A. Hildebrand, R. Vogelsang, S.H. Ambrose, J. Lesur, H. Wang, Early MIS 3 occupation of Mochena Borago Rockshelter, Southwest Ethiopian Highlands: implications for Late Pleistocene archaeology, palaeoenvironments and modern human dispersals, Quat. Int. 274 (2012) 38-54.

[16] F. Breglia, F. Arena, Le Grotte dell'Alta Valle dell'Esaro (Calabria). Dalla preistoria al medioevo, Atti del XXII Convegno Nazionale di Speleologia "Condividere I dati", Sessione scienza - C5, 30 Maggio al 2 Giugno 2015, Pertosa-Auletta (SA) 2015, pp. 516-521.

[17] C. Brolly, J. Parnell, S. Bowden, Raman spectroscopy: caution when interpreting organic carbon from oxidising environments, Planetary and Space Science 121 (2016) 53-59.

[18] C.E. Brown, Applied Multivariate Statistics in Geohydrology and Related Sciences, Springer, Berlin, 1998.

[19] M.K. Brust, G. Nash, Mine caves on the south-eastern flank of the Harz Mountains (Saxony-Anhalt, Germany), Memorie Instituto Italiano di Speleologia 28 (s. II) (2013) 71-72.

[20] K. Bu, J.V. Cizdziel, J. Russ, The source of iron-oxide pigments used in Pecos River style rock paints, Archaeometry 55 (6) (2013) 1088-1100.

[21] M. Camaiti, M. Bacci, M. Picollo, The identification of nitrates on carbonate substrates using diffuse reflectance infrared Fourier Transform DRIFTs in CaF 2 Matrix, 1998. http://irug.org/uploads/event/irug-2-postprints.pdf1998 (last accessed, 20 January 2016).

[22] J. Capel, F. Huertas, A. Pozzouli, J. Linares, Red ochre decorations in Spanish Neolithic ceramics: a mineralogical and technological study, J. Archaeol. Sci. 33 (2006) 1157-1166.

[23] F. Caron, F. d'Errico, P. Del Moral, F. Santos, J. Zilhão, The reality of Neanderthal symbolic behaviour at the Grotte du Renne, Arcy-sur-Cure, France, PLoS One 6 (6) (2011) 1-8.

[24] G. Cavallo, F. Fontana, F. Gonzato, A. Guerreschi, M.P. Riccardi, G. Sardelli, R. Zorzin, Sourcing and processing of ochre during the late upper Palaeolithic at Tagliente rock-shelter (NE Italy) based on conventional X-ray powder diffraction analysis, 2015. Archaeol. Anthropol. Sci. 1-13, http://dx.doi.org/10.1007/s12520-0150299-3.

[25] G. Cavallo, M.P. Riccardi, R. Zorin, Powder diffraction of yellow and red natural earths from Lessini Mountains in NE Italy. Technical article, Powder Diffract. (2015) JCPDS-ICDD.

[26] P. Chase, The Emergence of Culture. The Evolution of a Uniquely Human Way of Life, Springer, New York, 2006.

[27] V. Ciobotă, W. Salama, N. Tarcea, P. Rösch, M. El Aref, R. Gaupp, J. Popp, Identification of minerals and organic materials in Middle Eocene ironstones from the Bahariya Depression in the Western Desert of Egypt by means of micro-Raman spectroscopy, J. Raman Spectrosc. 43 (3) (2012) 405-410.

[28] V. Cloutier, R. Lefebvre, R. Therrien, M.M. Savard, Multivariate statistical analysis of geochemical data as indicative of the hydrogeochemical evolution of groundwater in a sedimentary rock aquifer system, J. Hydrol. 353 (3) (2008) 294-313.

[29] R.M. Cornell, U. Schewertmann, The Iron Oxides, Wiley-VCH Verlag GmbH \& Co., Weinheim, 2003.

[30] C. Couraud, Pour une étude méthodologique des colorants préhistoriques, Bulletin de la Société préhistorique française 80 (4) (1983) 104-110.

[31] C. Couraud, Pigments utilisés en Préhistoire. Provenance, préparation, mode d'utilisation, l'Anthropologie 92 (1) (1988) 17e-8.

[32] G. Cui, Q.B. Lai, L. Zhang, F.M. Wang, Quantitative measurements of sp3 content in DLC films with Raman spectroscopy, Surf. Coat. Technol. 205 (7) (2010) 1995-1999.

[33] R.E. de Aquino, J. Marques, M.C. Costa Campos, I. Amorim de Oliveira, A.S. Rabelo de Souza Bahia, L.A. Coutrim dos Santos, Characteristics of color and iron oxides of clay fraction in Archaeological Dark Earth in Apuí region, southern Amazonas, Geoderma 262 (2016) 35-44.

[34] D. de Faria, F.N. Lopes, Heated goethite and natural hematite: can Raman spectroscopy be used to differentiate them? Vib. Spectrosc. 45 (2) (2007) 117-121.

[35] D. de Faria, S. Venâncio Silva, M.T. de Oliveira, Raman microspectroscopy of some iron oxides and oxyhydroxides, J. Raman Spectrosc. 28 (11) (1997) 873-878.

[36] F. d'Errico, Gli archeologi raccolgono indizi sugli albori della mente moderna, Darwin 14 (3) (2006) 72-79.

[37] F. d'Errico, L. Backwell, P. Villa, I. Degano, J.J. Lucejko, M.K. Bamford, T.F.G. Higham, M.P. Colombini, P.B. Beaumont, Early evidence of San material culture represented by organic artifacts from Border Cave, South Africa, Proc. Natl. Acad. Sci. 103 (33) (2012) 13214-13219.
[38] F. d'Errico, C. Henshilwood, G. Lawson, M. Vanhaeren, A.-M. Tillier, M. Soressi, F. Bresson, B. Maureille, A. Nowell, J. Lakarra, L. Backwell, M. Julien, Archaeological evidence for the emergence of language, symbolism, and music: an alternative multidisciplinary perspective, Journal of World Prehistory 17 (1) (2003) 1-70.

[39] F. d'Errico, C.S. Henshilwood, M. Vanhaeren, K. van Niekerk, Nassarius kraussianus shell beads from Blombos Cave: evidence for symbolic behaviour in the Middle Stone Age, J. Hum. Evol. 48 (2005) 3-24.

[40] F. d'Errico, H. Salomon, C. Vignaud, C.B. Stringer, Pigments from the Middle Palaeolithic levels of Es-Skhul, J. Archaeol. Sci. 37 (2010) 3099-3110.

[41] F. d'Errico, R. García Moreno, R.F. Rifkin, Technological, elemental and colorimetric analysis of an engraved ochre fragment from the Middle Stone Age levels of Klasies River Cave 1, South Africa, J. Archaeol. Sci. 39 (4) (2012) 942-952.

[42] L. Dayet, Ochre resources from the Middle Stone Age sequence of Diepkloof Rock Shelter, Western Cape, South Africa, J. Archaeol. Sci. 40 (9) (2013) 3492-3505.

[43] L. Dayet, P.-J. Texier, F. Daniel, G. Porraz, Ochre resources from the middle stone age sequence of Diepkloof Rock Shelter, Western Cape, South Africa, J. Archaeol. Sci. 40 (2013) 3492-3505.

[44] L. Dayet, F. d'Errico, R. Garcia Moreno Mazel, Searching for consistencies in Châtelperronian pigment use, J. Archaeol. Sci. 44 (1) (2014) 180-193.

[45] R.A. Dart, P.B. Beaumont, Evidence of iron ore mining in Southern Africa in the Middle Stone Age, Curr. Anthropol. 10 (1) (1969) 127-128.

[46] S. Das, M.J. Hendry, Application of Raman spectroscopy to identify iron minerals commonly found in mine wastes, Chem. Geol. 290 (3-4) (2011) 101-108.

[47] F. Delamare, B. Guineau, Colors. The Story of Pigments and Dyes, Harry N. Abrams Inc., New York, 2000.

[48] L.A. Dimuccio, Geological setting, in: F. Larocca (Ed.), La Miniera Pre-protostorica di Grotta della Monaca (Sant'Agata di Esaro - Cosenza), Centro Regionale di Speleologia Enzo dei Medici 2005, pp. 25-30.

[49] L.A. Dimuccio, Karst and speleogenesis, in: F. Larocca (Ed.), La Miniera Preprotostorica di Grotta della Monaca (Sant'Agata di Esaro - Cosenza), Centro Regionale di Speleologia Enzo dei Medici 2005, pp. 31-36.

[50] L.A. Dimuccio, A. Garavelli, F. Vurro, Minerali metallici di interesse archeometrico della "Grotta della Monaca" (S. Agata d'Esaro - Cs), Plinius 22 (1999) 156-157.

[51] L.A. Dimuccio, A. Garavelli, D. Pinto, F. Vurro, Yukonite, $\mathrm{Ca}_{2} \mathrm{Fe}_{3}\left(\mathrm{AsO}_{4}\right)_{4}(\mathrm{OH}) \cdot 12 \mathrm{H}_{2} \mathrm{O}$ a rare hydrated Ca-Fe arsenate, from "Grotta della Monaca" (Sant'Agata d'Esaro, Cosenza - Italy). Prelyminar data, Plinius 26 (2001) 804-805.

[52] L.A. Dimuccio, F. Vurro, D. Pinto, A. Garavelli, The mineral resource, in: F. Larocca (Ed.), La Miniera Pre-protostorica di Grotta della Monaca (Sant'Agata di Esaro - Cosenza), Centro Regionale di Speleologia Enzo dei Medici 2005, pp. 37-42.

[54] N. Eastaugh, V. Walsh, T. Chaplin, R. Siddal, Pigment Compendium: A Dictionary and Optical Microscopy of Historical Pigments, Elsevier Ltd., UK-USA, 2008.

[55] B.S. Eiselt, R.S. Popelka-Filcoff, J.A. Darling, M.D. Glascock, Hematite sources and archaeological ochres from Hohokam and O'odham sites in central Arizona: an experiment in type identification and characterization, J. Archaeol. Sci. 38 (2011) 3019-3028.

[57] L.W. Ellis, S.C. Caran, M.D. Glascock, S.W. Tweddy, H. Neff, Appendix H: geochemical and mineralogical characterization of ochre from an archaeological context, in: S.L. Black, L.W. Ellis, D.G. Creel, G.T. Goode (Eds.), Hot Rock Cooking on the Greater Edwards Plateau: Four Burned Rock Midden Sites in West Central Texas, Texas Archaeological Research Laboratory, University of Texas at Austin, 1997.

[58] J. Erlandson, J.D. Robertson, C. Descantes, Geochemical analysis of eight red ochres from western North America, Am. Antiq. 64 (1999) 517-526.

[59] E. Frahm, Characterizing obsidian sources with portable XRF: accuracy, reproducibility, and field relationships in a case study from Armenia, J. Archaeol. Sci. 49 (2014) 105-125.

[60] E. Frahm, R.C.P. Doonan, The technological versus methodological revolution of portable XRF in archaeology, J. Archaeol. Sci. 40 (2013) 1425-1434.

[61] O. Frank, M. Zukalova, B. Laskova, J. Kürti, J. Koltai, L. Kavan, Raman spectra of titanium dioxide (anatase, rutile) with identified oxygen isotopes $(16,17,18)$, Phys. Chem. Chem. Phys. 14 (42) (2012) 14567-14572.

[62] R.L. Frost, M.L. Weier, P.A. Williams, P. Leverett, J.T. Kloprogge, Raman spectroscopy of the sampleite group of minerals, J. Raman Spectrosc. 38 (5) (2007) 574-583.

[63] G. Giachi, E. De Carolis, P. Pallecchi, Raw materials in Pompeian paintings: characterization of some colours from the archaeological site, Mater. Manuf. Process. 24 (9) (2009) 1015-1022.

[64] M.A. Gomez, L. Becze, R.I.R. Blyth, J.N. Cutler, G.P. Demopoulos, Molecular and structural investigation of yukonite (synthetic \& natural) and its relation to arseniosiderite, Geochim. Cosmochim. Acta 74 (20) (2010) 5835-5851.

[65] A. Garavelli, D. Pinto, F. Vurro, M. Mellini, C. Viti, T. Balic-Žunic, G. Della Ventura Yukonite from the Grotta della Monaca cave, Sant'Agata di Esaro, Italy: characterization and comparison with cotype material from the Daulton mine, Yukon, Canada, Can. Mineral. 47 (2009) 39-51.

[66] A. Geniola, F. Larocca, F. Vurro, Approvvigionamento di risorse minerarie nella Grotta della Monaca (Sant'Agata di Esaro - Cosenza), Materie prime e scambi nella Preistoria italiana. Atti della XXXIX Riunione Scientifica dell'Istituto Italiano di Preistoria e Protostoria, 25-27 novembre 2004, Firenze, vol. III, 2006 pp. 1349-1359.

[67] S. Gialanella, R. Belli, G. Dalmeri, I. Lonardelli, M. Mattarelli, M. Montagna, L. Toniutti, Artificial or natural origin of hematite-based red pigments in archaeological contexts: the case of Riparo Dalmeri (Trento, Italy), Archaeometry 53 (5) (2011) 950-962.

[68] G. Goldenberg, A. Maass, G. Steffens, H. Steuer, Hematite mining during the linear ceramics culture in the area of the Black Forest, South West Germany, in: T. Stöll, G. Körlin, G. Steffens, J. Cierny (Eds.), Man and Mining - Mensch und Bergbau, Der Anschnitt, 16, 2003, pp. 179-186. 
[69] A. Heginbotham, A. Bezur, M. Bouchard, J.M. Davis, K. Eremin, J.H. Frantz, L. Glinsman, L.-A. Hayek, D. Hook, V. Kantarelou, A. Germanos Karydas, L. Lee, J. Mass, C. Matsen, B. McCarthy, M. McGath, A. Shugar, J. Sirois, D. Smith, R.J. Speakman, An evaluation of inter-laboratory reproducibility for quantitative XRF of historic copper alloys, in: P. Mardikian, et al., (Eds.), Metal 2010. Proceedings of the International Conference on Metal Conservation, Charleston, South Carolina, USA, October 11-15, 2010, Clemson University Press 2010, pp. 244-255.

[70] K. Helwig, Iron oxide pigments in artist's pigments, in: B.H. Berrie (Ed.), A Handbook of Their History and Characteristics, 4, National Gallery of Art, Washington 2007, pp. 39-95.

[71] C.S. Henshilwood, Fully symbolic sapiens behaviour: innovation in the Middle Stone Age at Blombos Cave, South Africa, in: C. Stringer, P. Mellars (Eds.), Rethinking the Human Revolution: New Behavioural and Biological Perspectives on the Origins and Dispersal of Modern Humans, University of Cambridge Press, Cambridge 2007, pp. 123-132.

[72] C.S. Henshilwood, F. d'Errico (Eds.), Homo Symbolicus: The Dawn of Language, Imagination and Spirituality, John Benjamins, Amsterdam, 2011

[73] C.S. Henshilwood, F. d'Errico, I. Watts, Engraved ochres from Middle Stone Age levels at Blombos Cave, South Africa, J. Hum. Evol. 57 (2009) 27-47.

[74] C.S. Henshilwood, F. d'Errico, K.L. Van Nierkek, Y. Coquinot, Z. Jacobs, S.-E. Lauritzen, M. Menu, R. García-Moreno, A 100,000-year-old ochre-processing workshop at Blombos Cave, South Africa, Science 334 (2011) 1-53.

[75] T. Hodgskiss, An investigation into the properties of the ochre from Sibudu, KwaZulu-Natal, South Africa, South. Afr. Humanit. 24 (2012) 99-120.

[76] A. Högberg, L. Larsson, Lithic technology and behavioural modernity: new results from the Still Bay site, Hollow Rock Shelter, Western Cape Province, South Africa, J. Hum. Evol. 61 (2) (2011) 133-155.

[77] E. Hovers, S. Illani, O. Bar-Yosef, B. Vandermeersch, An early case of color symbolism. Ochre used by modern humans in Qafzeh cave, Curr. Anthropol. 44 (2003) 491-522.

[78] F.C. Howell, Observations on the earlier phases of the European Lower Palaeolithic, Am. Anthropol. 68 (2) (1966) 88-201.

[79] Husson, F., Josse, J., Le, S., Mazet, J., 2013. FactoMineR: multivariate exploratory data analysis and data mining with R. R Package Version 1.24 [online] (available at: https://cran.r-project.org/ - last access April 2016).

[80] A.V. Kiehn, G.A. Brook, M.D. Glascock, J.Z. Dake, L.H. Robbins, A.C. Campbell, M.L. Murphy, Fingerprinting specular hematite from mines in Botswana, Southern Africa, in: M.D. Glascock, R.J. Speakman, R.S. Popelka-Filcoff (Eds.), Archaeologica Chemistry: Analytical Techniques and Archaeological Interpretation, ACS Symposium Series No. 968, American Chemical Society, Washington DC 2007, pp. 460-479.

[81] A. Kingery-Schwartz, R.S. Popelka-Filcoff, D.A. Lopez, F. Pottier, P. Hill, M. Glascock, et al., Analysis of geological ochre: its geochemistry, use, and exchange in the US Northern Great Plains, Open Journal of Archaeometry 1 (e15) (2013) 72-76.

[82] C. Knight, Language co-evolved with the rule of law, Mind \& Society 7 (2008) 109-128.

[83] C. Knight, Introduction: perspectives on the evolution of language in Africa, in: R Botha, C. Knight (Eds.), The Cradle of Language, Oxford University Press, Oxford 2009, pp. 1-15.

[84] C. Knight, Language, ochre, and the rule of law, in: R. Botha, C. Knight (Eds.), The Cradle of Language, Oxford University Press, Oxford 2009, pp. 281-303.

[85] C. Koukouli-Chrysanthaki, G. Weisgerber, Prehistoric ochre mines on Thasos, in: C. Koukouli-Chrysanthaki, A. Müller, S. Papadopoulos (Eds.), Thasos: Matières Premières et Technologie de la Préhistoire à nos jours, Actes du Colloque Internationa Thasos, Liménaria, De Boccard, Paris 1999, pp. 129-144 26-29 septembre 1995.

[86] P. Kristova, L.J. Hopkinson, K.J. Rutt, The effect of the particle size on the fundamental vibrations of the $\left[\mathrm{CO}_{3}^{2-}\right]$ anion in calcite, J. Phys. Chem. A 119 (20) (2015) 4891-4897.

[87] R.A. Kühnel, H.J. Roorda, J.J. Steensma, The crystallinity of minerals. A new variable in pedogenetic processes: a study of goethite and associated silicates in laterites, Clay Clay Miner. 23 (1975) 349-354

[88] T.S. Kurtikyan, V.A. Hayrapetyan, M.M. Mehrabyan, P.C. Ford, Six-coordinate nitrito and nitrato complexes of manganese porphyrin, Inorg. Chem. 53 (22) (2014) 11948-11959.

[89] A. Ietto, A.M. Barilaro, G. Calligaro, C. Mancuso, Elementi per una revisione dei rapporti Appennino Arco Calabro, Boll. Soc. Geol. Ital. 111 (1992) 193-215

[90] G. Imer, A. Dorner-Reisel, Micro-Raman studies on DLC coatings, Adv. Eng. Mater. 7 (8) (2005) 694-705

[91] F. Larocca, Una miniera di età protostorica in Calabria. La Grotta della Monaca di Sant'Agata d'Esaro (Cosenza), L'Universo 1, Istituto Geografico Militare, 2001.

[92] F. Larocca (Ed.), La miniera pre-protostorica di Grotta della Monaca (Sant'Agata di Esaro - Cosenza), Centro Regionale di Speleologia "Enzo dei Medici", Roseto Capo Spulico, 2005.

[93] F. Larocca, Grotta della Monaca. Una miniera pre-protostorica di rame e ferro in Calabria, Atti del XX Congresso Nazionale di Speleologia, Iglesias, 27-30 aprile 2007, Memorie dell'Istituto Italiano di Speleologia, s. II, vol. XXI, 2008, pp. 273-280 Bologna.

[94] F. Larocca, Grotta della Monaca: a prehistoric copper and iron mine in the Calabria Region (Italy), in: P. Anreiter, et al., (Eds.), Mining in European History and Its Impact on Environment and Human Societies, Proceedings for the 1st Mining in European History-Conference of the SFB-HIMAT, Innsbruck, 12-15 November 2009, Innsbruck University Press 2010, pp. 267-270.

[95] F. Larocca, La "miniera" di Grotta della Monaca, Archeologia Viva 149 (2011) 66-72.

[96] F. Larocca, Chamber of secrets. Exploring the Grotta della Monaca, Current World Archaeology 44 (2011) 46-50.
[97] F. Larocca, Grotta della Monaca (Sant'Agata di Esaro - Cosenza). Utensili e tecniche estrattive di età eneolitica per l'acquisizione di minerali di rame, L'età del rame in Italia. Atti della XLIII Riunione Scientifica dell'Istituto Italiano di Preistoria e Protostoria, Bologna, 26-29 novembre 2008 2011, pp. 663-668.

[98] F. Larocca, Grotta della Monaca (Calabria, Italia meridionale). Una miniera neolitica per l'estrazione dell'ocra, in: M. Borrell, et al., (Eds.), Xarxes al Neolitic, Actes Congrés Internacional, Gavà/Bellaterra, 2-4 febrer 2011, Rubricatum 5, Gavà 2012, pp. 249-256.

[99] F. Larocca, L.A. Dimuccio, Importanti scoperte nella Grotta della Monaca, Speleologia 37 (1997) 129-130.

100] F. Larocca, D. Lorusso, La Grotta della Monaca a Sant'Agata d'Esaro (Cosenza), Speleologia 38 (1998) 5-12.

[101] F. Larocca, M. De Falco, La miniera preistorica di Grotta della Monaca/Grotta della Monaca, a Prehistoric Mine, Speleologia 68 (2013) 74-75.

[102] F. Larocca, C. Levato, From the imprint to the tool: the identification of prehistoric mining implements through the study of dipping traces. The case of Grotta della Monaca in Calabria (Italy), in: P. Anreiter, et al., (Eds.), Mining in European History and its Impact on Environment and Human Societies, Proceedings for the 2nd Mining in European History Conference of the FZ HiMAT, 7-10 November 2012, Innsbruck, 2013, pp. 21-26.

[103] F. Larocca, F. Breglia, L'alta Valle dell'Esaro e le sue miniere preistoriche, Speleologia 71 (2014) 30-36.

[104] F. Larocca, F. Arena, Una parte per il tutto. Un caso di deposizione ossea isolata di età paleolitica a Grotta della Monaca (Calabria), Il Paleolitico e il Mesolitico in Italia: nuove ricerche e prospettive di studio. Atti dell'Incontro Annuale di Preistoria e Protostoria, Genova, 4-5 febbraio 2016, pp. 1-8.

[105] M.A. Legodi, D. De Waal, The preparation of magnetite, goethite, hematite and maghemite of pigment quality from mill scale iron waste, Dyes Pigments 74 (2007) 161-168.

[106] M.A. Legodi, D. De Waal, Raman spectroscopic study of ancient South African domestic clay pottery, Spectrochim. Acta A Mol. Biomol. Spectrosc. 66 (2007) 135-142.

[107] C. Levato, F. Larocca, The prehistoric iron mine of Grotta della Monaca (Calabria, Italy), Anthropologica et Præhistorica 125/2014 (2015) 1-2.

[108] D.G. Lewis, V.C. Farmer, Infrared absorption of surface hydroxyl groups and lattice vibration in lepidocrocite $(\gamma-\mathrm{FeOOH})$ and boehmite $(\gamma$-AlOOH$)$, Clay Miner. 21 (1986) 93-100.

[109] M. Lombard, The gripping nature of ochre: the association of ochre with Howiesons Poort adhesives and Later Stone Age mastics from South Africa, J. Hum. Evol. 53 (2007) 406-419.

[110] S. Lorenzoni, G. Orsi, E. Zanettin-Lorenzoni, Metallogenesis in the tectonic units and lithogenetic environments of Calabria (Southern Italy), Memorie di Scienze Geologiche XXXV (1983) 411-428.

[111] H. Liu, T. Chen, C. Qing, Q. Xie, R.L. Frost, Confirmation of the assignment of vibrations of goethite: an ATR and IES study of goethite structure, Spectrochimica Acta Part a-Molecular and Biomolecular Spectroscopy 116 (2013) 154-159.

[112] B.L. MacDonald, R.G.V. Hancock, A. Cannon, A. Pidruczny, Geochemical characterization of ochre from central coastal British Columbia, Canada, J. Archaeol. Sci. 38 (2011) 3620-3630

[113] B. MacDonald, R. Hancock, A. Cannon, R. McNeill, A. Pidruczny, Elemental analysis of ochre outcrops in Southern British Columbia, Canada, Archaeometry 55 (6) (2013) 1020-1033.

[114] E.A. Mackey, S.J. Christopher, R.M. Lindstrom, S.E. Long, A.F. Marlow, K.E. Murphy, R.L. Paul, R.S. Popelka-Filcoff, S.A. Rabb, J.R. Sieber, R.O. Spatz, B.E. Tomlin, L.J. Wood, J.H. Yen, L.L. Yu, R. Zeisler, S.A. Wilson, M.G. Adams, Z.A. Brown, P.L. Lamothe, J.E. Taggart, C. Jones, J. Nebelsick, Certification of three NIST renewal soil standard reference materials for element content: SRM 2709a San Joaquin soil, SRM 2710a Montana soil I, and SRM 2711a Montana soil II, National Institute of Standards and Technology, Special Publication 260-172 (2010).

[115] P. Makreski, G. Jovanovski, S. Dimitrovska, Minerals from Macedonia XIV. Identification of some sulfate minerals by vibrational (infrared and Raman) spectroscopy, Vib. Spectrosc. 39 (2) (2005) 229-239.

[116] L. Manscalco, Ochre containers and trade in the central Mediterranean Copper Age, Am. J. Archaeol. 93 (4) (1989) 537-541.

[117] S. Marino, C. Levato, Una miniera nella Grotta del Tesauro di Sant'Agata di Esaro (Cosenza, Calabria), Atti del XX Congresso Nazionale di Speleologia, Iglesias 2730 aprile 2007, Memorie dell'Instituto Italiano di Speleologia, s. II, vol. XXI, 2008, pp. 267-272

[118] W. Martens, R.L. Frost, J.T. Kloprogge, P.A. Williams, Raman spectroscopic study of the basic copper sulphates - implications for copper corrosion and 'bronze disease', J. Raman Spectrosc. 34 (2) (2003) 145-151.

[119] S. McBrearty, A.S. Brooks, The revolution that wasn't: a new interpretation of the origin of modern human behaviour, J. Hum. Evol. 39 (2000) 453-563.

[121] K.H. Michaelian, S.L. Zhang, S. Yariv, I. Lapides, Low-frequency Raman spectra of kaolinite alkali halide complexes, Appl. Clay Sci. 13 (4) (1998) 233-243.

[122] C.M. Müller, B. Pejcic, L. Esteban, C. Delle Piane, M. Raven, B. Mizaikoff, Infrared attenuated total reflectance spectroscopy: an innovative strategy for analyzing mineral components in energy relevant systems, 2014. Scientific REP RTS 1-11 (4) 6764, http://dx.doi.org/10.1038/srep06764.

[123] H. Neff, Neutron activation analysis for provenance determination in archaeology, in: E. Ciliberto, G. Spoto (Eds.), Modern Analytical Methods in Art and Archaeology, Chemical Analysis Series 155, Wiley, New York 2000, pp. 81-134.

[125] M.-P. Pomiès, G. Morin, C. Vignaud, XRD study of the goethite-hematite transformation: application to the identification of heated prehistoric pigments, European Journal of Solid State Inorganic Chemistry 35 (1998) 9-25. 
[126] M.-P. Pomiès, M. Menu, C. Vignaud, Red Palaeolithic pigments: natural hematite or heated goethite? Archaeometry 41 (2) (1999) 275-285.

[127] R.S. Popelka-Filcoff, J.D. Robertson, M.D. Glascock, C. Descantes, Sourcing Red Ochres by Instrumental Trace Analysis, SAS Bulletin, 2005 9-11 Spring Summer.

[128] R.S. Popelka-Filcoff, J.D. Robertson, M.D. Glascock, C. Descantes, Trace element characterization of ochre from geological sources, J. Radioanal. Nucl. Chem. 272 (2007) 17-27.

[129] R.S. Popelka-Filcoff, E.J. Miska, J.D. Robertson, M.D. Glascock, H. Wallace, Elemental analysis and characterization of ochre sources from southern Arizona, J. Archaeol. Sci. 35 (2008) 752-762.

[130] R.S. Popelka-Filcoff, C.E. Lenehan, K. Walshe, J.W. Bennet, A. Stopic, P. Jones, A. Pring, J.S. Quinton, A. Durham, Characterisation of ochre sources in South Australia by neutron activation analysis (NAA), Journal of the Anthropological Society of South Australia 35 (2012) 81-106.

[131] T.D. Price, J.H. Burton, An Introduction to Archaeological Chemistry, Springer Science + Business Media, New York, 2012.

[132] G. Quarta, F. Larocca, M. D'Elia, V. Gaballo, M. Macchia, G. Palestra, L. Calcagnile, Radiocarbon dating the exploitation phases of the Grotta della Monaca cave in Calabria, southern Italy: a prehistoric mine for the extraction of iron and copper, in: A.J.T. Jull, C. Hatté (Eds.),Proceeding of the 21st International Radiocarbon Conference, Radiocarbon, 55, 2013, pp. 1246-1251 (2-3).

[133] G. Rajnovich, Reading Rock Art: Interpreting the Indian Rock Paintings of the Canadian Shield, Natural Heritage/NATURAL History Inc., Toronto, Canada, 1994.

[134] R.F. Rifkin, Assessing the efficacy of red ochre as a prehistoric hide tanning ingredient, Journal of African Archaeology 9 (2) (2011) 31-158.

[135] R. Rifkin, L. Dayet, A. Queffelec, B. Summers, M. Lategan, F. d'Errico, Evaluating the photoprotective effects of red ochre on human skin by in vivo SPF assessment: implications for human evolution, adaptation and dispersal, PLoS One 10 (9) (2015), e0136090.

[136] W. Roebroeks, M.J. Sier, T. Kellberg Nielsen, D. De Loecker, J.M. Parés, C.E.S. Arps, H.J. Mücher, Use of red ochre by early Neanderthals, Proc. Natl. Acad. Sci. 109 (6) (2012) 1889-1894.

[137] D.C. Roper, A comparison of contexts of red ochre use in Palaeoindian and Upper Palaeolithic sites, North American Archaeologists 12 (1991) 289-301.

[138] M. Rossano, Making friends, making tools, and making symbols, Curr. Anthropol. 51 (1) (2010) 89-98.

[139] D.E. Rosso, F. d'Errico, J. Zilhão, Stratigraphic and spatial distribution of ochre and ochre processing tools at Porc-Epic Cave, Dire Dawa, Ethiopia, Quat. Int. 343 (2014) 85-99.

[140] H. Salomon, C. Vignaud, Y. Coquinot, L. Beck, C. Stringer, D. Strivay, F. d'Errico, Selection and heating of colouring materials in the Mousterian level of Es-Skhul (c. 100000 years BF, Mount Carmel, Israel), Archaeometry 54 (4) (2012) 698-722.

[141] H. Salomon, C. Vignaud, S. Lahlil, N. Menguy, Solutrean and Magdalenian ferruginous rocks heat-treatment: accidental and/or deliberate action? J. Archaeol. Sci. 55 (2015) 100-112.

[142] R. Scadding, V. Winton, V. Brown, An LA-ICP-MS trace element classification of ochres in the Weld Range environ, Mid West region, Western Australia, J. Archaeol. Sci. 54 (2015) 300-312.

[144] P.A. Schroeder, N.D. Melear, R.J. Pruett, Quantitative analysis of anatase in Georgia kaolins using Raman spectroscopy, Appl. Clay Sci. 23 (5-6) (2003) 299-308.

[145] A.D. Scott, S. Warmlander, J. Mazurek, S. Quirke, Examination of some pigments, grounds and media from Egyptian cartonnage fragments in the Petrie Museum, University College London, J. Archaeol. Sci. 36 (2009) 923-932.

[146] U. Schwertmann, P. Cambier, E. Murad, Properties of goethites of varying crystallinity, Clay Clay Miner. 33 (5) (1985) 369-378.

[147] Siivola, J., Schmid, R., 2007. List of mineral abbreviations. Recommendations by the IUGS Subcommission on the Systematics of Metamorphic Rocks: Web version 01.02.07 (https://www.bgs.ac.uk/scmr/docs/papers/paper_12.pdf - Last access August 2016).

[148] M.A. Smith, B. Fankhauser, M. Jercher, The changing provenance of red ochre at Puritjarra rock shelter, central Australia: Late Pleistocene to present, Proceedings of the Prehistoric Society 64 (1998) 275-292.

[149] V. Šontevska, G. Jovanovski, P. Makreski, A. Raškovska, B. Šoptrajanov, Minerals from Macedonia. XXI vibrational spectroscopy as Identificational tool for some phyllosilicate minerals, Acta Chim. Slov. 55 (4) (2008) 757-766.

[150] M.D. Stafford, G.C. Frison, D. Stanford, G. Zeimans, Digging for the color of life: paleoindian red ochre mining at the Powars II site, Platte County, Wyoming, U.S.A, Geoarchaeology 18 (1) (2003) 71-90.
[151] U. Stockmann, S.R. Cattle, A.B. Minasny, A.B. McBratney, Utilizing portable X-ray fluorescence spectrometry for in-field investigation of pedogenesis, Catena 139 (2016) 220-231.

[152] J. Sun, Z. Wu, H. Cheng, Z. Zhang, R.L. Frost, A Raman spectroscopic comparison of calcite and dolomite, Spectrochimica Acta Part a-Molecular and Biomolecular Spectroscopy 117 (2014) 158-162.

[153] P.S.C. Taçon, Ochre, clay, stone and art: the symbolic importance of minerals as a life-force among aboriginal peoples of northern and central Australia, in: N. Boivin, M.A. Owoc (Eds.), Soils, Stones and Symbols: Cultural Perceptions of the Mineral World, UCL Press 2004, pp. 31-42.

[154] K.B. Tankersley, K.O. Tankersley, N.R. Shaffer, M.D. Hess, J.S. Benz, F.R. Turner, M.D. Stafford, G.M. Zeimans, G.C. Frison, They have a rock that Bleeds: sunrise red ochre and its early Palaeoindian occurrence at the Hell Gap site, Wyoming, Plains Anthropol. 40 (1995) 185-194.

[156] Z. Tomić, P. Makreski, B. Gajić, Identification and spectra-structure determination of soil minerals: Raman study supported by IR spectroscopy and X-ray powder diffraction, J. Raman Spectrosc. 41 (5) (2010) 582-586.

[158] F. Ugolini, Soil colors, pigments and clays in paintings in Soil and Culture, in: E.R. Landa, C. Feller (Eds.), Soil and Culture, Springer 2010, pp. 67-82.

[159] J. Velo, Ochre as medicine: a suggestion for the interpretation of the archaeological record, Curr. Anthropol. 25 (5) (1984) 674.

[160] J. Velo, The problem of ochr, Mank. Q. 26 (3-4) (1986) 229-237.

[161] L. Wadley, Putting ochre to the test: replication studies of adhesives that may have been used for hafting tools in the Middle Stone Age, J. Hum. Evol. 49 (2005) 587-601.

[162] L. Wadley, Cemented ash as a receptacle of work surface for ochre powder production at Sibudu, South Africa, 58,000 years ago, J. Archaeol. Sci. 37 (2010) 2397-2406.

[163] L. Wadley, T. Hodgskiss, M. Grant, Implications for complex cognition from the hafting of tools with compound adhesives in the Middle Stone Age, South Africa, Proc. Natl. Acad. Sci. 106 (24) (2009) 9590-9594.

[164] H. Wackernagel, Multivariate Geostatistics, Springer, 1995.

[165] Y.Y. Wang, F.X. Gan, H.X. Zhao, Inclusions of black-green serpentine jade determined by Raman spectroscopy, Vib. Spectrosc. 66 (2013) 19-23.

[166] I. Watts, Red ochre, body-painting, and language: interpreting the Blombos ochre, in: R. Botha, C. Knight (Eds.), The Cradle of Language, Oxford University Press 2009, pp. 62-92.

[167] I. Watts, The pigments from Pinnacle point cave 13B, Western Cape, South Africa, J Hum. Evol. 59 (2010) 392-411.

[168] W.E. Wendt, "Art mobilier" aus der Apollo 11-Grotte in Südwest-Afrika, Acta Praehist. Archaeol. 5 (1974) 1-42.

[169] G. Weisgerberg, J. Cierny, C. Koukouli-Crysanthaki, Zu paläolithisher Gewinnung roter Farbmineralien auf der Insel Thasos, in: Ü. Yalcin (Ed.), Anatolian Metal IV, Der Anschnitt 21, 2008, pp. 179-190.

[170] E.E. Wreschner, The red hunters: further thoughts on the evolution of speech, Curr. Anthropol. 17 (4) (1976) 717-719.

[171] E.E. Wreschner, Red ochre and human evolution: a case for discussion, Curr Anthropol. 21 (1980) 631-644.

[172] E.E. Wreschner, R. Bolton, K.W. Butzer, H. Delporte, A. Hausler, A. Heinrich, A Jacobson-Widding, T. Malinowski, C. Masset, S. Miller, A. Ronen, R. Solecki, P.H. Stephenson, L. Thomas, H. Zollinger, Red ochre and human evolution: a case for discussion, Curr. Anthropol. 21 (5) (1980) 631-644.

[173] J. Williams, Clam Gardens: Aboriginal Mariculture on Canada's West Coast, New Star Books, Vancouver, 2006.

[174] D.S. Whitley, Introduction to Rock Art Research, Left Coast Press, Walnut Creek, California, 2005.

[175] T. Wynn, F.L. Coolidge, Beyond symbolism and language. An introduction to supplement 1, working memory, Curr. Anthropol. 51 (1) (2010) 5-16.

[176] K.E. Young, C.A. Evans, K.V. Hodges, J.E. Bleacher, T.G. Graff, A review of the handheld X-ray fluorescence spectrometer as a tool for field geologic investigations on Earth and in planetary surface exploration, Appl. Geochem. 72 (2016) 77-87.

[177] E. Cheilakou, M. Troullinos, M. Koui, Identification of pigments on Byzantine wall paintings from Crete (14th century AD) using non-invasive Fiber Optics Diffuse Reflectance Spectroscopy (FORS), Journal of Archaeological Science 41 (2014) 541-555.

[178] R Core Team, R: a Language and Environment for Statistical Computing, 2013. R Foundation for Statistical Computing, Vienna, Austria, 2013 [online]. Available. http://www.R-project.org/. 